Örge Yaşar, F. ve Çiftçi, B. (2021). Türkçe öğretmenlerinin yazımı karıştırılan kelimelere yönelik görüşleri: Çanakkale ili örneği. Ana Dili Eğitimi Dergisi, 9(3), 889-910.

Ana Dili Eğitimi Dergisi
Journal of Mother Tongue Education
www.anadiliegitimi.com
Geliş/Received: 01.04 .2021 Kabul/Accepted: 25.06 .2021
Araştırma Makalesi / Research Paper

\title{
Türkçe Öğretmenlerinin Yazımı Karıştırılan Kelimelere Yönelik Görüşleri: Çanakkale ili Örneği*
}

\author{
Funda ÖRGE YAŞAR ${ }^{* *}$ \\ Burcu ÇiFTÇi**
}

\begin{abstract}
Öz
Bu çalışmanın amacı, Türkçe öğretmenlerinin yazımı karıştırılan kelimelere yönelik görüşlerini ortaya koymaktır. Araştırmanın katılımcılarını 2019-2020 eğitim öğretim yılında Çanakkale ili merkez ilçeye bağlı devlet ya da özel okulların 5, 6, 7 ve 8. sınıflarında okuyan öğrencilerin Türkçe dersine giren 45 Türkçe öğretmeni oluşturmaktadır. Nitel araştırma yönteminin kullanıldığı bu araştırmada veriler, yarı yapılandırılmış görüşme formlarıyla toplanmıştır. Araştırma sonuçlarına göre Türkçe öğretmenlerinin \%14,67'si öğrencilerin kitap okumamasını, \%10,67'si ise yazım kurallarının sürekli değişmesini, kelimelerin öğrenciler tarafından yanlış yazılmasının temel sebebi olarak görmektedir. Ayrıca öğretmenlerin \%28,73'ü kitle iletişim araçlarında kelimelerin özensiz bir şekilde yazıldığını, \%21,28'i kitle iletişim araçlarının yazım yanlışlarını kalıcı hâle getirdiğini ifade etmiştir.
\end{abstract}

Anahtar Kelimeler: Yazımı karıştırılan kelimeler, yarı yapılandırılmış görüşme, Türkçe öğretmenleri, Çanakkale ili örneği

\section{The Opinions of Turkish Language Teachers Regarding Misspelled Words: A Sample From Çanakkale Province}

\begin{abstract}
In this study, the aim was to reveal the opinions of Turkish language teachers regarding misspelled words. The study participants were 45 Turkish language teachers who taught the Turkish language in the fifth, sixth, seventh, and eighth grades in state or private schools affiliated with the central district of Çanakkale Province in the 2019-2020 academic year. In this study in which a qualitative research method was used, the data were collected with semi-structured interview forms. According to the results of the research, $14.67 \%$ of the Turkish language teachers thought that the main reason that students misspelled words was the fact that students do not read books, and $10.67 \%$ of the teachers thought that the constant change in spelling rules was the main reason. In addition, $28.73 \%$ of the teachers stated that words are written carelessly in the mass media, and $21.28 \%$ of them stated that spelling mistakes in the mass media make such mistakes permanent. Keywords: Misspelled words, semi-structured interview, Turkish language teachers, sample from Çanakkale province
\end{abstract}

\footnotetext{
* Bu çalışma, "Türkçe Öğretmeni ve Adaylarının Yazımı Karıştırılan Kelimelere Yönelik Görüşleri” adlı yüksek lisans tezinden üretilmiş olup "Çanakkale Onsekiz Mart Üniversitesi Bilimsel Araştırma Projeleri Koordinasyon Birimince Desteklenmiştir. Proje Kodu: SYL-2020-3168”

** Doç. Dr., Çanakkale Onsekiz Mart Üniversitesi, Eğitim Fakültesi, Türkçe ve Sosyal Bilimler Eğitimi Bölümü, Çanakkale, fundaorge@comu.edu.tr, ORCID: orcid.org/0000-0002-8207-9685

${ }^{* * *}$ Bilim Uzmanı, Çanakkale Onsekiz Mart Üniversitesi, Lisansüstü Eğitim Enstitüsü, Türkçe ve Sosyal Bilimler Eğitimi Anabilim Dalı, Çanakkale, burcuciftci3272@gmail.com, ORCID: orcid.org/0000-0002-3102-7789
} 


\section{Giriş}

Insanlar, var oldukları andan itibaren çevrelerindeki diğer canlılarla iletişim hâlinde olmuşlardır. Bu iletişim, ilk başlarda tamamen içgüdüsel olarak gerçekleşmiştir. Bu bağlamda "ilk insanların içinde yaşadığı doğa ile bütünleşip yaşamlarını sürdürmeye çalışırken, her doğasal etki ve iletiye içgüdüsel tepki gösterdikleri, doğa ile kendiliğinden oluşan bir iletişim kurdukları kabul edilmektedir" (Gönenç, 2007: 92). illk başlarda sadece içgüdüsel olarak sürdürülen iletişim, insanların bir arada yaşamaya başlaması, birlikte avlanması gibi toplumsal gelişmelerle birlikte bilinçli bir iletişime dönüşmüştür. İnsanlar, hayvan boynuzlarını kullanıp çıkardıkları sesler aracılığıyla birbirlerini uyarmış; mağara duvarlarına çizdikleri resimlerle farklı konularda bilgilendirmişlerdir. Zamanla, insanların konuşmaya başlamasıyla birlikte iletişim şeklinde de bazı değişiklikler olmuştur. Böylece, mağara duvarlarına resim çizmek, duman yoluyla iletişim kurmak gibi zaman alıcı ve yorucu yollar yerine, konuşarak anlaşma tercih edilir hâle gelmiştir (Örge Yaşar, 2020). İnsanlık tarihi için bir diğer önemli gelişme ise yazının icadı olmuştur. Bu sayede insanların, kendilerini ifade etmelerinde konuşmanın dışında yazmadan da yararlanmaları mümkün hâle gelmiştir. "Insanoğlu elde ettiği deneyimlerini gelecek nesillere yazı aracılığıyla aktararak bugünkü bilim, kültür ve medeniyet seviyesine ulaşmıştır" (Karatay, 2011: 1030).

"Yazma, hayatımıza okulla birlikte giren ve geç gelişen bir anlatma becerisidir. Bu nedenle özellikle eğitim hayatı boyunca ön plana çıkar ve başarıyı doğrudan etkileyecek bir etken olur" (Kurudayıoğlu ve Çimen, 2020: 3901). Hayatımızda bu kadar önemli bir yere sahip olan yazma, duygu ve düşüncelerin etkili bir şekilde kâğıda aktarılmasıdır. Yazılan metnin güzel ve etkileyici olması hem zengin bir kelime hazinesine sahip olmayı hem eleştirel ve yaratıcı düşünmeyi hem de iyi bir gözlemci olmayı gerektirir. Sıralanan bu özelliklerin yanında; kelimelerin anlamlarına uygun kullanılması, dilin cümle yapısının gözetilmesi, kelimelerin doğru yazılması, noktalama işaretlerinin doğru ve yerinde kullanılması gibi kurallara dikkat edilmiş olması, metinlerin değerini artırır (Örge Yaşar ve Çiftçi, 2020). Bu kurallardan biri olan yazım kuralları, Güncel Türkçe Sözlük'te, "bir dildeki sözcüklerin yazılış biçimlerini belirleyen kurallar" şeklinde tanımlanmıştır. Bu kurallar, bir "dilin konuşulmasında ve yazılmasında birlik sağlanması, o dilin korunması ve gelecek nesillere doğru bir şekilde aktarılması bakımından son derece önemlidir" (Balyemez, 2012: 42).

Yazım kuralları "konuşma dilinde oluşan modaların, kısa süreli telaffuzların, bir hevese bağlı veya başka dillerin etkisiyle bir süreliğine ortaya çıkan temayüllerin meşrulaşmasına engel olmak ve yazı dilinde istikrarı sağlamak için gereklidir" (Demir, 2018: 124). Bu bağlamda sözvarlığımızdaki sözcüklerin belirli kurallar çerçevesinde herkesçe doğru yazıımasını sağlamak amacıyla Yazım Kılavuzu'ndan yararlanılmaktadır.

Ülkemizde yazım kılavuzu hazırlamak, yazmak ve yayımlamak görevi, Anayasa'nın 134. maddesine dayalı olarak çıkarılan 11.10.2011 tarih ve 664 sayılı Atatürk Kültür, Dil ve Tarih Yüksek Kurumu Teşkilat ve Görevleri Hakkında Kanun Hükmünde Kararname'nin 10. maddesinin ç fıkrasıyla Türk Dil Kurumuna verilmiştir [Resmî Gazete, Sayı: 28103 (Mükerrer)]. "Bu temel kaynakta 'yazım kuralları, ses, harf ve alfabe, bazı sözcük ve eklerin yazılışı, sayıların yazılışı, büyük harflerin kullanıldığı yerler, birleşik sözcüklerin yazılışı, alıntı sözcüklerin yazııışı, yabancı özel adların yazııışı, noktalama işaretleri, kısaltmalar, simgeler ve dizin' yer almaktadır" (Akdağ, 2020: 70). Yazım Kılavuzu, sahip olduğu bu özelliğiyle herkes için önemli ve vazgeçilmez bir başvuru kaynağıdır.

Yazım Kılavuzu'nun tarihine bakıldığında kılavuzun, genellikle köklü değişiklikler yerine düzeltmeler yoluna gidilerek bazen isim değişikliğiyle bazen de tıpkıbasım olarak yeniden yayımlandığı görülmektedir. Bu bağlamda Türk Dil Kurumunun kuruluşundan önce 1928 yılında Dil Encümeni tarafından hazırlanan Imlâ Lûgati dışında, Türk Dil Kurumu tarafından Imlâ Kılavuzu (1941, 1948, 1956, 1957, 1960, 1962), Yeni İmlâ Kılavuzu (1965, 1966, 1967, 1969), Yeni Yazım (İmlâ) Kılavuzu [1970 (aynı yıl içerisinde iki kez basılmıştır)], Yeni Yazım Kılavuzu $(1973,1975,1977,1980,1981)$, Imlâ Kılavuzu $(1985,1988,1993,1996,2000)$, Yazım Kılavuzu $(2005,2008,2009,2012)$ gibi değişik adlarla yirmi yedi kez basımı yapılmıştır (TDK, 2012: I-VIII). Yayımlanan kılavuzlarda yapılan düzenlemeler her zaman yeterli olmamış, her basım yeni tartışmaları da beraberinde getirmiştir. Bu tartışma ve eleştiriler, genel olarak birleşik kelimelerin yazımı, düzeltme işaretinin kullanımı ve yazım kuralları çerçevesinde yoğunlaşmışır. Örneğin metcezir kelimesi 1941 yılında yayımlanan Imlâ Kılavuzu'nda (s. 128) 
meddücezir, 2005 yılında yayımlanan Yazım Kılavuzu'nda (s. 334) medcezir, 2012 yılında yayımlanan Yazım Kılavuzu'nda (s. 389) metcezir şeklinde; silüet kelimesi 1960 yılında yayımlanan Imlâ Kılavuzu'nda (s. 156) silûet, 1965 yılında yayımlanan Yeni Imlâ Kılavuzu'nda (s. 201) siluet, 2005 yılında yayımlanan Yazım Kılavuzu'nda (s. 414) silüet şeklinde; floresans kelimesi ise 1965 yılında yayımlanan Yeni Imlâ Kılavuzu'nda (s. 108) floresans, 1988 yılında yayımlanan Imlâ Kılavuzu'nda (s. 117) flüoresans, 2005 yılında yayımlanan Yazım Kılavuzu'nda (s. 211) Floresans, 2012 yılında yayımlanan Yazım Kılavuzu'nda (s. 248) floresans şeklinde yazılmıştır. Bu örnekleri çoğaltmak mümkündür.

Sancak, Alver ve Durukan (2009) "Türk Dil Kurumunun İmlâ/ Yazım Kılavuzlarındaki Değişiklikler Üzerine Bir İnceleme" adlı çalışmalarında 1996, 2000 ve 2005 yıllarında yayımlanan yazım kılavuzlarını incelemiş; 1996 ve 2005 yılları arasında yayımlanan kılavuzlarda kelime sayılarında bir artışın gerçekleştiğini, bu artışın 1996 ve 2000 kılavuzlarında daha fazla olduğunu tespit etmişlerdir. Yine, kurallar bölümünde 2000, 2005 kılavuzları arasındaki farklılıkların 1996, 2000 kılavuzlarına göre daha fazla olduğu sonucuna ulaşmışlardır. Bu durum, yazımı karıştırılan kelimeler konusunda bir fikir birliğine varılamadığını göstermekte ve yazım kurallarının sürekli değişmesiyle öğrencilerde bir kafa karışıklı̆ının yaşandığını gözler önüne sermektedir. Bununla birlikte yeşilzeytin kelimesinin bitişik, siyah zeytin kelimesinin ise ayrı yazılması; büyük harflerle yapılan kısaltmalarda harflerden sonra gelen noktaların kaldıııması ancak Türkçe (T.) ve Türkiye Cumhuriyeti (T.C.) kısaltmalarının bu kuralın dışında tutulması vb. bazı istisnaların olması hem yazım kurallarının öğretimini hem de öğrenimini zorlaştırmakta, kurallarda bazı istisnai durumların olması da ne yazık ki öğrencilere mantıklı açıklamalar yapabilmenin önüne geçmektedir.

Alanyazın incelendiğinde, bu beceriyi kazandırması beklenen Türkçe öğretmenlerinden yazım yanlışlarının nedenlerine ilişkin görüş alan bir tek çalışmaya rastlanmıştır. Akkaya (2013) tarafından yapılan bu çalışmada 6. sınıf Türkçe dersine giren öğretmenlere "6. sınıf öğrencilerinin yazım yanlışlarının nedenleri nelerdir?" sorusu yöneltilmiş; bu nedenlerin ağırlıklı olarak ilgi ve dikkat eksikliğinden, sınav türlerinden ve öğrencilerin yazım kurallarını içeren kaynaklardan etkili bir şekilde yaralanmadıklarından kaynaklandığı tespit edilmiştir. Türkçe öğretmenlerinden yazımı karıştırılan kelimeler konusunda görüş alan ve onların, öğrencilere yazma becerisinin kazandırılmasında ne derece etkili olabildiklerini ya da yazımı karıştııılan kelimelere yönelik bilgi düzeylerinin ne durumda olduğunu tespit eden bir çalışmaya ise rastlanmamıştır. Bu bağlamda çalışmanın amacı, Türkçe öğretmenlerinin yazımı karıştıılan kelimelere yönelik görüşlerini almak, yazımı karıştıılan kelimelerin neden doğru yazılamadığını tespit etmek ve elde edilen görüşlerden hareketle çözüm önerileri getirebilmektir.

\section{Araştırmanın Modeli}

\section{Yöntem}

Türkçe öğretmenlerinin yazımı karıştıılan kelimelere yönelik görüşlerini belirleyebilmek için nitel araştırma yöntemi kullanılmıştır. "Nitel araştırma, çok çeşitli yöntemlere ve veri kaynaklarına uyarlanabilmekle birlikte, incelenen bireylerin gözünden dünyayı izleyerek deneyimlerini anlamanın ve yorumlamanın amaçlandığı öznel bir yaklaşımdı" (Walter, 2020: 20). Nitel araştırmalarda gözlem, görüşme, doküman analizi vb. veri toplama tekniklerinden yararlanılır (Yıldırım ve Şimşek, 2018). Bu tekniklerden biri olan görüşme, "bireylerin, çeşitli konulardaki bilgi, düşünce, tutum ve davranışları ile bunların olası nedenlerinin öğrenilmesinde" (Karasar, 2005: 166) kullanılır. Görüşmeler; kaynakların ulaşılabilir olma durumu ve araştırmada toplanmak istenen verilerin özelliklerine göre yapılandırılmış, yapılandırılmamış, yarı yapılandırılmış, etnografik, odak grup görüşmesi olarak farklı türlere (Büyüköztürk, Kılıç Çakmak, Akgün, Karadeniz ve Demirel, 2020) ayrılsa da eğitim bilimleri alanında yapılan çalışmalarda yapılandırılmış, yapılandırılmamış ve yarı yapılandııılmış görüşmeler daha yaygın kullanılır (Patton, 1987; Robson, 1993; Wragg, 1994; Gall, Borg ve Gall, 1996, Holstein ve Gubrium, 1997'den akt. Türnüklü, 2000). Bunlardan yarı yapılandırılmış görüşmeler "hem sabit seçenekli cevaplamayı hem de ilgili alanda derinlemesine gidebilmeyi birleştirir" (Büyüköztürk vd., 2020: 159). Bu bağlamda, araştırma konusuyla ilgili verilerin toplanmasında nitel araştırma yöntemlerinden yarı yapılandırılmış görüşme tekniği kullanılmıştır. 


\section{Örneklem/ Araştırma grubu}

Bu araştırmanın çalışma grubunu, Türkçe öğretmenleri oluşturmaktadır. Araştırma grubu, seçkisiz örnekleme çeşidinden basit seçkisiz örnekleme yöntemi kullanılarak belirlenmiştir. Basit seçkisiz örneklemede "araştırma evrenindeki her bir ögenin ya da birimin örnekleme girme olasılığı eşittir" (Gürbüz ve Şahin, 2018: 131). Bu belirleme sonrasında 2019-2020 eğitim öğretim yılında Çanakkale ili merkez ilçeye bağlı devlet ya da özel okulların 5, 6, 7 ve 8. sınıflarında okuyan öğrencilerin Türkçe dersine giren 45 Türkçe öğretmeni, çalışmanın araştırma grubunu oluşturmuştur. Öğretmenlerin kimliklerini gizlemek için kadın öğretmenler K1, K2, K3, K4, K5...; erkek öğretmenler ise E1, E2, E3, E4, E5... şeklinde kodlanmıştır. Türkçe öğretmenlerine ait demografik özellikler Tablo 1'de verilmiştir.

Tablo 1.

Görüşmeye Katılan Türkçe Öğretmenlerinin Demografik Özellikleri

\begin{tabular}{|c|c|c|c|}
\hline Değişkenler & & $\mathrm{f}$ & $\%$ \\
\hline \multicolumn{4}{|l|}{ Cinsiyet } \\
\hline Kadın & & 34 & 75,56 \\
\hline \multirow[t]{2}{*}{ Erkek } & & 11 & 24,44 \\
\hline & Toplam & 45 & 100 \\
\hline \multicolumn{4}{|c|}{ En Son Mezun Olunan Eğitim Programı } \\
\hline Lisans Tamamlama & & 1 & 2,22 \\
\hline Lisans (Eğitim Fakültesi) & & 31 & 68,89 \\
\hline Lisans (Diğer) & & 9 & 20,00 \\
\hline Yüksek Lisans & & 4 & 8,89 \\
\hline \multirow[t]{2}{*}{ Doktora } & & - & 0,00 \\
\hline & Toplam & 45 & 100 \\
\hline \multicolumn{4}{|l|}{ Mesleki Kıdem } \\
\hline $0-5$ yıl & & 3 & 6,67 \\
\hline 6-10 yıl & & 2 & 4,44 \\
\hline $11-15$ yıl & & 7 & 15,56 \\
\hline $16-20$ yıl & & 17 & 37,78 \\
\hline \multirow[t]{2}{*}{21 yıl ve üstü } & & 16 & 35,55 \\
\hline & Toplam & 45 & 100 \\
\hline \multicolumn{4}{|l|}{ Görevli Olunan Okul Türü } \\
\hline Devlet Ortaokulu & & 39 & 86,67 \\
\hline \multirow[t]{2}{*}{ Özel Ortaokul } & & 6 & 13,33 \\
\hline & Toplam & 45 & 100 \\
\hline \multicolumn{4}{|c|}{ Türkçe Dersi Okutulan Sınıf/Sınıflar } \\
\hline 5. sinif & & 27 & 24,77 \\
\hline 6. sinif & & 28 & 25,69 \\
\hline 7. sinıf & & 28 & 25,69 \\
\hline 8. sinif & & 26 & 23,85 \\
\hline
\end{tabular}

Tablo 1'de görüldüğü üzere araştırma grubundaki öğretmenlerin \%75,56'sı kadın, \%24,44'ü erkektir. Öğretmenlerin mezun oldukları program göz önüne alındığında \%68,89'unun Eğitim Fakültesi Lisans, \%20'sinin 4 yıllık Fakülte, \%8,89'unun Yüksek Lisans, \%2,22'sinin Lisans Tamamlama mezunu olduğu görülmektedir. Görüşmeye katılan öğretmenler, mesleki kıdem yönüyle değerlendirildiğinde büyük çoğunluğunun $(\% 37,78)$ 16-20 yıl arası aktif görevde olduğu görülürken 21 yıl ve üstü görev yapan öğretmenlerin çokluğu da $(\% 35,55)$ dikkat çekmektedir. Öğretmenlerin \%15,56'sı 11-15 yıl, $\% 6,67$ 'si 0-5 yıl, \%4,44'ü ise 6-10 yıl arası mesleki kıdeme sahiptir. Bununla birlikte öğretmenlerin \%86,67'si devlet okullarında, \%13,33'ü özel okullarda çalışmaktadır. Öğretmenlerin birden fazla sınıfta 
derse girmeleri durumu ise Türkçe dersi okutulan 5, 6, 7 ve 8. sınıflar açısından dengeli bir dağılım yaratmıştır.

\section{Veri Toplama Araçları}

Türkçe öğretmenlerinin yazımı karıştırılan kelimelere yönelik görüşlerini belirleyebilmek amacıyla araştırmacı tarafından hazırlanan 15 soruluk yarı yapılandırılmış görüşme formu kullanıımıştır. Görüşme formundaki sorulardan beş tanesi kişisel bilgilere, on tanesi ise araştırma konusuna yönelik hazırlanmıştır. Türkçe öğretmenlerine uygulanacak yarı yapılandırılmış görüşme formu, araştırmada iç geçerliliği sağlayabilmek için biri Türkçe Eğitimi, diğeri Eğitim Bilimleri alanında uzman olmak üzere iki alan uzmanının görüşüne sunulmuş; alan uzmanlarından, görüşme formunda yer alan soruların anlaşılır olup olmadığını ve soruların ele alınan araştırma konusunu kapsayıp kapsamadığını belirlemeleri istenmiştir. Alan uzmanlarının görüşleri çerçevesinde sorular tekrar gözden geçirilerek gerekli düzeltmeler yapılmış ve örneklem dışı tutulan üç Türkçe öğretmeni ile pilot görüşme yapılmıştır. Yapılan pilot görüşme sonrasında elde edilen verilerden hareketle yarı yapılandırılmış görüşme formundaki soruların istenilen verileri sağladığı kanısına varılarak Türkçe öğretmenlerine bu görüşme formu uygulanmıştır.

\section{Verilerin Toplanması}

Bu çalışmanın verileri, araştırmacı tarafından hazırlanan yarı yapılandırılmış görüşme formunun 2019-2020 eğitim öğretim yılında Çanakkale ili merkez ilçesine bağlı özel ve devlet ortaokullarında görev yapan Türkçe öğretmenlerine 16.12.2019-30.12.2019 tarihleri arasında uygulanmasıyla toplanmıştır.

\section{Verilerin Analizi}

Türkçe öğretmenlerinin yazımı karıştıılan kelimelere yönelik görüşlerini belirleyebilmek amacıyla oluşturulan yarı yapılandırılmış görüşme formlarından elde edilen veriler, içerik analizine tabi tutularak değerlendirilmiştir. "iç̧erik analizinde temelde yapılan işlem, birbirine benzeyen verileri belirli kavramlar ve temalar çerçevesinde bir araya getirmek ve bunları okuyucunun anlayabileceği bir biçimde düzenleyerek yorumlamaktır" (Şahin, 2010: 189). Bu bağlamda yapılan değerlendirmeler sonucunda bulgular 10 ana tema altında gruplandırımıştır. İlgili temalar: 1. Öğretmenlerin öğrenciler tarafından en çok hata yapıldığını düşündükleri konu başlıklarını sıralamaları/ işaretlemeleri, 2. Öğretmenlerin kelimelerin öğrenciler tarafından yanlış yazıımasının temel sebeplerine yönelik görüşleri, 3. Öğretmenlerin kitle iletişim araçlarının kelimelerin yanlış yazımındaki etkisine yönelik görüşleri, 4. Öğretmenlerin kelimelerin yazımıyla ilgili tereddüte düştüklerinde başvurdukları kaynaklara yönelik görüşleri, 5. Öğretmenlerin öğrencilerin yazım kılavuzu/ sözlük kullanmalarının gerekliliğine yönelik görüşleri, 6. Öğretmenlerin Türk Dil Kurumunun kendi web sayfasındaki Yazım Kılavuzu uygulamasını kaldırarak kelimelerin yazımını, anlamlarıyla birlikte Güncel Türkçe Sözlük başlığı altında vermesine yönelik görüşleri, 7. Öğretmenlerin Türkçe Dersi Öğretim Programında (Ortaokul 5, 6, 7 ve 8. Sınıflar) yazma becerisine ilişkin kazanımlara yönelik görüşleri, 8. Öğretmenlerin Türkçe dersinde yazım kuralları konusunu işlerken karşılaştıkları sorunlara yönelik görüşleri, 9 . Öğretmenlerin Türkçe dersinde yazım kuralları konusunu işlerken karşılaştıkları sorunları gidermek amacıyla getirdikleri öneriler, 10. Öğretmenlerin Türkçe dersinde yazım kuralları konusunun öğrencilere daha iyi kazandırılabilmesi için getirdikleri öneriler olarak belirlenmiş, veriler bu temalar altında yorumlanmıştır. Öğretmen görüşlerinin daha iyi yansıtılabilmesi için doğrudan alıntılara yer verilmiştir.

\section{Geçerlik ve Güvenirlik}

Araştırmada iç geçerliliği sağlayabilmek için hazırlanan yarı yapılandırılmış görüşme formu iki alan uzmanının görüşüne sunulmuş ve alan uzmanlarından görüşme formunda yer alan soruların anlaşılır olup olmadığı, soruların ele alınan araştırma konusunu kapsayıp kapsamadığı konusunda görüş bildirmeleri istenmiştir. Alan uzmanlarının görüşleri çerçevesinde sorular gözden geçirilmiş ve gerekli düzeltmeler yapılmışır. Yarı yapılandııılmış görüşme formunun uygulanmasıyla elde edilen veriler analiz edilerek değerlendirilmiş, yapılan değerlendirmelerin doğruluğu alan uzmanlarının görüşleri ile 
sınanmıştır. Yapılan değerlendirmelerin güvenilir olduğunun tespit edilmesiyle, elde edilen bulgular tablolar halinde sunularak yorumlanmıştır. Bununla birlikte katılımcıların görüşlerinden doğrudan alıntılara da yer verilmiştir.

\section{Araştırma ve Yayın Etiği}

Bu çalışmada "Yükseköğretim Kurumları Bilimsel Araştırma ve Yayın Etiği Yönergesi" kapsamında uyulması belirtilen tüm kurallara uyulmuştur. Yönergenin ikinci bölümü olan "Bilimsel Araştırma ve Yayın Etiğine Aykırı Eylemler" başlığı altında belirtilen eylemlerden hiçbiri gerçekleştirilmemiştir.

\section{Etik Kurul İzni}

Kurul adı = Çanakkale Onsekiz Mart Üniversitesi Sosyal Bilimler ve Eğitim Bilimleri Etik Kurulu Karar tarihi $=27.11 .2019$

Toplantı sayısı $=10$

\section{Bulgular}

Araştırmanın bu bölümünde Türkçe öğretmenlerinin, yazımı karıştırılan kelimelere yönelik görüşleri incelenmiştir.

Tablo 2.

Öğretmenlerin Öğrenciler Tarafından En Çok Hata Yapıldığını Düşündükleri Konu Başıklarını Sıralamalarına Yönelik Görüşleri

\begin{tabular}{clcc}
\hline Tercih Edilme Sıralaması & \multicolumn{1}{c}{ Konu Başlığı } & f & $\%$ \\
\hline 1 & Yazımı Karıştırılan Kelimeler & 11 & 31,43 \\
2 & Birleşik Kelimelerin Yazımı & 10 & 28,57 \\
3 & Büyük Harflerin Yazımı & 7 & 20 \\
4 & Sayıların Yazımı & 3 & 8,57 \\
4 & Ek ve İkilemelerin Yazımı & 3 & 8,57 \\
6 & Kısaltmaların Yazımı & 1 & 2,86 \\
\hline
\end{tabular}

Tablo 2'de öğretmenlerin öğrenciler tarafından en çok hata yapıldığını düşündükleri konu başlıklarını belirlemeye yönelik yaptıkları sıralama görülmektedir. Öğretmenler; öğrencilerin en çok yazımı karıştırılan kelimeler konusunda hata yaptıklarını düşünmektedirler. Bunu sırasıyla birleşik kelimelerin yazımı ve büyük harflerin yazımı izlerken sayıların yazımı ile ek ve ikilemelerin yazımı dördüncülüğü paylaşmaktadır. Öğretmenler, öğrencilerin yazımında en az zorlandıkları konu başlığı olarak da kısaltmaların yazımı konusunda karar kılmışlardır. Görüşmeye katılan 45 öğretmenden 10'u bu soru kapsamında bir sıralama yapmamış, onun yerine öğrencilerin en çok zorlandıklarını düşündükleri konu başlıklarını işaretlemişlerdir. Bu nedenle sadece öğretmenlerden $35^{\prime}$ inin bu soruya verdiği yanıtlar değerlendirilmiştir. İşaretleme yapan 10 katılımcıya ait veriler ise Tablo 3'te verilmiştir.

Tablo 3.

Öğretmenlerin Öğrenciler Tarafından En Çok Hata Yapıldığını Düşündükleri Konu Başıklarını işaretlemelerine Yönelik Görüşleri

\begin{tabular}{ll}
\hline Konu Başlı̆ı & $f$ \\
Büyük Harflerin Yazımı & 8 \\
Birleşik Kelimelerin Yazımı & 9 \\
Yazımı Karıştırılan Kelimeler & 8 \\
Sayıların Yazımı & 7 \\
Kısaltmaların Yazımı & 5 \\
Ek ve İkilemelerin Yazımı & 7 \\
\hline
\end{tabular}


Tablo 3'te öğretmenlerin öğrenciler tarafından en çok hata yapıldığını düşündükleri konu başlıklarını belirlemeye yönelik yaptıkları işaretlemeler gösterilmiştir. Öğretmenler birden fazla konu başlığına işaret koymuşlardır. Buna göre 10 öğretmenden 9'u öğrencilerin en çok birleşik kelimelerin yazımı konusunda zorlandıklarını düşünürken bunu sekizer kişi ile büyük harflerin yazımı ve yazımı karıştırılan kelimeler izlemektedir. Öğretmenlere göre, öğrencilerin en az hata yaptıkları konu başlı̆ı ise kısaltmaların yazımıdır.

Tablo 4.

Öğretmenlerin Kelimelerin Öğrenciler Tarafından Yanlış Yazılmasının Temel Sebeplerine Yönelik Görüşleri

\begin{tabular}{lcc}
\hline Kod & $f$ & $\%$ \\
\hline Kitap okumamaları. & 11 & 14,67 \\
Sürekli değişen yazım kuralları. & 8 & 10,67 \\
Teknoloji kullanımı. & 8 & 10,67 \\
Dikte çalışmasının yapılmaması. & 8 & 10,67 \\
Yazım yanlışlarının diğer derslerde pekiştirilmemesi. & 8 & 10,67 \\
Çevrelerinde yanlış yazımları sıkça görmeleri. & 8 & 10,67 \\
Öğrencilerin konuştukları gibi yazması. & 5 & 6,67 \\
Öğrencilerin Yazım Kılavuzu ve Sözlük kullanmamaları. & 4 & 5,33 \\
Öğrencilerin ilkokulda el yazısını kullanmaları. & 4 & 5,33 \\
Öğrencilerin farkında olmaması. & 4 & 5,33 \\
Öğrencilerin yazım kurallarını önemsememesi. & 4 & 5,33 \\
Öğrencilerin hızlı ve aceleci tutumu. & 2 & 2,67 \\
Unutkanlık. & 1 & 1,32 \\
\hline & 75 & 100 \\
\hline
\end{tabular}

Tablo 4'te öğretmenlerin kelimelerin öğrenciler tarafından yanlıs yazılmasının temel sebeplerine yönelik görüşleri yer almaktadır. Öğretmenlerin \%14,67'si temel sebep olarak öğrencilerin kitap okumamalarını göstermiştir. Öğrencilerin kitap okumama nedenini doğru kitap seçimi yapamamalarına bağlayan $\mathrm{K} 7$, öğrencilerin çevrelerinde kelimelerin yanlış yazımlarına sıkça rastlamalarına da dikkat çekmiştir. K7 bu konudaki düşüncelerini şu sözlerle dile getirmiştir:

"Öğrencilerin kelimeleri yanlış yazıyor olmalarının başlıca sebebi okumuyor olmalarıdır. Çocuklar okumadıkları ya da doğru kitap seçemedikleri için kelime hazinelerine katkıda bulunamıyorlar. Bundan dolayı da günlük hayatlarında çok sınırlı kelimeler ile yazıyorlar, konuşuyorlar. Kelimelerin yanlış yazılmasındaki diğer önemli bir sebep ise öğrencilerin çevrelerinde doğrulardan çok yanlış yazımlar ile karşılaşmalarıdır. Kitaplarda, gazetelerde, sosyal medyada, reklam panolarında, televizyonda vb. pek çok yerde bolca yazım yanlışı ile karşılaşıyorlar. Bir süre sonra da yanlışlar yerleşiyor."

Öğretmenlerin \%10,67'si öğrencilerin kelimeleri yanlış yazmalarını, yazım kurallarının sürekli değişmesine bağlamaktadır. Yazım kurallarının sürekli değişmesinden yakınan K6, yayınlarda yazım kurallarına dikkat edilmediğini de vurgulamıştır:

"Sürekli olarak değişen yazım kuralları, öğrencilerin aklını karıştırmaktadır. Hangi kelime bitişik yazılır, hangi kelime ayrı yazılır? Ayrıca ilkokulda el yazısı kullanmaları da yanlış yazma sebeplerinden biri. Televizyon gibi medya yayınlarında uyulmayan kurallar öğrencilerimizin yanlış bilgiler edinmesine neden olmaktadır."

K2 ise öğrencilerin, kelimeleri yanlış yazmalarının temel sebebini dikte çalışması yapılmamasıyla ilişkilendirerek görüşlerini şu sözlerle ifade etmiştir:

"Dikte yaptırılmaması, çalışma kitaplarına sadece bir kelimelik cevaplar yazılması ve artık öğrencilerin neredeyse hiç kalem kağıtla yazı yazmaması. Yazı yazmaktan korkan hatta nefret eden bir nesil doğdu çünkü artık yazı yazmıyorlar hiçbir derste." 
K1 ise diğer katılımcılardan farklı olarak öğrencilerin kelimeleri yanlış yazmalarının sebebini bir öneriden hareketle açıklamıştır:

"ilkokul müfredatının tamamıyla değiştirilmesi gerektiğini, daha da sadeleştirilmesi gerektiğini düşünmekteyim. Illkokulda sadece okuma ve yazma olmalı. Yazım kuralları ve noktalama işaretleri üzerinde durulmalı. Ilkokul sınavlarının test değil de yazılı sınav olması gerektiğini düşünmekteyim. Çocuklar ortaokula geldiklerinde bir paragraf dahi olsa kendilerini ifade edebilmeliler."

Tablo 5.

Öğretmenlerin Kitle Iletişim Araçlarının Kelimelerin Yanlış Yazımındaki Etkisine Yönelik Görüşleri

\begin{tabular}{|c|c|c|}
\hline Kod & $f$ & $\%$ \\
\hline Kitle iletişim araçlarında yanlışlar önemsenmiyor. & 27 & 28,73 \\
\hline Kitle iletişim araçları yazım yanlışlarını kalıcı hale getiriyor. & 20 & 21,28 \\
\hline Saçma yazımlar kazandırıyor. & 16 & 17,02 \\
\hline Televizyon olumsuz yönde etkiliyor. & 6 & 6,38 \\
\hline Sosyal medya kullanımı olumsuz yönde etkiliyor. & 6 & 6,38 \\
\hline Telefon kullanımı olumsuz yönde etkiliyor. & 6 & 6,38 \\
\hline $\begin{array}{l}\text { Haber programlarının kelime kullanım yönüyle özensiz oluşu olumsuz yönde } \\
\text { etkiliyor. }\end{array}$ & 5 & 5,32 \\
\hline Gazetelerde yazımlara dikkat edilmiyor. & 5 & 5,32 \\
\hline Bilgisayar kullanımı olumsuz yönde etkiliyor. & 2 & 2,13 \\
\hline Tablet kullanımı olumsuz yönde etkiliyor. & 1 & 1,06 \\
\hline Toplam & 94 & 100 \\
\hline
\end{tabular}

Tablo 5'te öğretmenlerin kitle iletişim araçlarının kelimelerin yanlış yazımı üzerindeki etkisine yönelik görüşlerine ait dağılım yer almaktadır. Buna göre öğretmenlerin hepsi, kitle iletişim araçlarının kelimelerin yanlış yazımı üzerinde büyük bir etkiye sahip olduğunu ifade etmiştir. Kitle iletişim araçlarında kelimelerin çok özensiz bir şekilde yazıldığına değinen öğretmenlerden K24 ve K31 bu durumun öğrenciler üzerinde yanlış bir tutuma da neden olabileceğini şu sözlerle dile getirmişlerdir:

"Kitle iletişim araçları ögrrencinin ailesi ya da öğretmenlerinden çok daha etkili maalesef. Karşılaştıkları yanlışları hemen alıp uygulamaya çalışıyorlar. Doğrusunu görünce de çok şaşırıyorlar. Özellikle gençlerin kendi aralarındaki kelimeleri kısaltma eğilimi ya da ingilizce konuşma eğilimi maalesef ki bizleri etkiliyor." (K24)

"Öğrenciler teknoloji ile beraber bilgiye hızlı bir şekilde ulaşırken yanlış bilgilere de maruz kalıyor. Hızlı olurken tamamen yanlış bilgiler elde ediyorlar. Ayrıca yazışmalarında kullandıkları sanal dil kurallarını günlük hayatta da kullanıyorlar. Bu durum da tamamen yanlış kalıplar ve kelimeler ortaya çıkarıyor." (K31)

Kitle iletişim araçlarının, yazım yanlışlarını kalıcı hale getirdiğine dikkat çeken K6 ve E7 ise düşüncelerini şu sözlerle açıklamışlardır:

"Kitle iletişim araçlarında belirli bir denetim mekanizması işlemiyor. Özel isimler küçük yazılıyor. Özellikle kısaltmalara gelen eklerin okunuşu ile ilgili sürekli hata. MGK'nın, TDK'nın, SGK'nın şeklinde sunum yapılıyor. Bizler de bu hataları düzeltirken sorun yaşıyoruz öğrencilerimizle." (K6)

"Kitle iletişim araçları kesinlikle dilimizi olumsuz yönde etkilemektedir. Dil konusunda faydadan çok zararı olduğunu düşünüyorum. TV programlarındaki yanlış yazılan kelimelerin zihinlerde doğru olarak kodlanması da maalesef bu zararlı etkileri pekiştiriyor. Gazete, dergi, internet sayfaları vb. mecralarda sıklıkla yanlıs yazılan kelimeler de cabası..." (E7) 
Tablo 6.

Öğretmenlerin Bir Kelimenin Yazımıyla ilgili Tereddüte Düştüklerinde Başvurdukları Kaynaklara Yönelik Görüşleri

\begin{tabular}{lcc}
\hline Kod & $f$ & $\%$ \\
\hline TDK Sitesi & 26 & 42,62 \\
Yazım Kılavuzu & 22 & 36,08 \\
TDK Sözlük & 12 & 19,67 \\
Ekşi Sözlük & 1 & 1,63 \\
\hline
\end{tabular}

Tablo 6'da öğretmenlerin bir kelimenin yazımı konusunda emin olamadıkları zaman başvurdukları kaynaklarla ilgili görüşlerine ait dağılım yer almaktadır. Buna göre öğretmenler, en çok $(\% 42,62)$ Türk Dil Kurumuna ait internet sitesinden yararlanmaktadır. E7 buna ilişkin görüşünü şu sözlerle dile getirmiştir:

"TDK'nın internet sayfasını ziyaret edip oradan doğru yazımına bakarım. Teknoloji çağında yaşadığımız için malum, sözlük kullanmak biraz zor geliyor. Erişimi sınırsız ve kolay olduğu için tdk.gov.tr adresinden çevrimiçi sözlük kullanmak en kolay ve hızlı yol diye düşünüyorum."

E7 kodlu katılımcı gibi Türk Dil Kurumunun internet sitesinden yararlandıklarını ifade eden K5 ve K7, TDK'nin sitesine yönelik bir konuya dikkat çekmeyi de ihmal etmemişlerdir. Katılımcıların bu konudaki görüşleri şöyledir:

"TDK'ya başvuruyoruz. Ama sürekli güncelleme yapıyor, bunlardan haberimiz olmuyor." (K5)

"Kelimelerin yazımıyla ilgili tereddüte düştügüm zaman TDK'yi kullanıyorum. TDK'yi kullanma sebebim ülke genelinde uygulanan sınavlarda TDK yazım kurallarının baz alınıyor olmasıdır. TDK'yi kullanıyor olmama rağmen her zaman tatmin edici cevaplar da bulamayabiliyorum." (K7)

TDK'nin internet sitesine karşılık başvuru kaynağı olarak Yazım Kılavuzunu savunan K8 ve K32 konuya ilişkin görüşlerini şu sözlerle dile getirmişlerdir:

"TDK Sözlük ve TDK imla kılavuzu ilk başvuru kaynaklarımdır." (K8)

"Sadece TDK sözlüğe bakarım. Internet sitelerine güvenmem." (K32)

E8, ilk kaynak olarak İmla Kılavuzunu görmekle birlikte internetten yararlanması gerektiği durumlarda diğer katııımcılardan farklı olarak Ekşi Sözlük'ten yararlandığını “ilk başvurduğumuz kaynak imla kılavuzudur. Kılavuza ulaşamazsam internetten "Ekşi Sözlük"ten yararlanırım." cümleleriyle ifade etmiştir.

Tablo 7.

Öğretmenlerin Öğrencilerin Yazım Kılavuzu/Sözlük Kullanmalarının Gerekliliğine Yönelik Görüşleri

\begin{tabular}{|c|c|c|c|}
\hline Kod & & $\mathrm{f}$ & $\%$ \\
\hline Mutlaka kullanmalılar. & & 35 & 77,78 \\
\hline Kullanmayı bilmiyorlar. & & 6 & 13,33 \\
\hline Gerekli fakat taşıması zor olduğu için internetten faydalanabilirler. & & 4 & 8,89 \\
\hline & Toplam & 45 & 100 \\
\hline
\end{tabular}

Tablo 7'de öğretmenlerin öğrencilerin Yazım Kılavuzu/ Sözlük kullanmalarının gerekliliği konusundaki görüşlerine ait dağılım yer almaktadır. Öğretmenlerin $\% 77,78^{\prime} i$ öğrencilerin mutlaka yazım kılavuzu/ sözlük kullanmaları gerektiğini ifade etmiştir. Sözlük ve yazım kılavuzu kullanımının öğrencilerin kelime hazinelerine katkı sağlayacağını savunan K7, K32 ve E8 konuya ilişkin görüşlerini şu sözlerle dile getirmişlerdir:

"Öğrencilerimin yazım kılavuzu ve sözlük kullanmalarını önemsiyorum. Yazım kılavuzu ve sözlükleri derslerimde de sıklıkla kullanıyorum. Sözlük kullanımının öğrencilerimin kelime hazinelerini ve temel dil becerilerini doğrudan etkileyeceğini düşünüyorum." (K7) 
"Kesinlikle kullanmaları gerekir, hatta alışkanlık edinmeleri gerekir. Çünkü günlük hayatta sürekli bir bilmediği kelimeyle karşılaşabilir ya da yazdığı sözcüğün doğru olup olmadığını bilme gereksinimi duyabilir. Böyle olunca da mutlaka sözlükten bakması gerekmektedir." (K32)

"Özellikle Türkçe derslerinde öğrencilerin anlamını bilmedikleri sözcükleri sözlükten anında bulmaları ve bu sözcükleri cümle içinde kullanarak daha iyi kavramalıdır. Sözlük ve imla kılavuzu mutlaka kullanılmalıdır." (E8)

K29, öğrencilerin mutlaka yazım kılavuzu/ sözlük kullanmaları gerektiğini ifade ederken bir öneri de getirmiştir:

"Mutlaka kullanılmalı ve Milli Eğitim ücretsiz ders kitapları dağıtırken yazım kılavuzu ve Türkçe sözlüğü de dağıtmalı."

Öğrencilerin mutlaka yazım kılavuzu/ sözlük kullanmaları gerektiğini ancak sözlük taşımanın da zor olduğunu vurgulayan K30 ve K33 konuya ilişkin görüşlerini şu cümlelerle dile getirmişlerdir:

"Öğrenciler yazım kılavuzu ve sözlük kullanmaya üşeniyorlar. Internetten bakmayı tercih ediyorlar. Ayrıca çantaları çok ağır olduğu için yanlarında taşımaları da zor oluyor." (K30)

"Gerekli. Ancak yeterli derece kullanım alışkanlığı kazandırılamıyor. Öğretmeni sözlük olarak kullanmaya çalışıyorlar. Buna izin vermesek de sözlük taşımak zor geliyor." (K33)

Öğrencilerin yazım kılavuzu/ sözlük kullanmalarının gerekliliği konusunda görüş bildiren E4, E6 ve $\mathrm{E7}$ aynı zamanda internetten de faydalanılabileceğini düşündüklerini şu sözlerle dile getirmişlerdir:

"Akıllı telefonlardan TDK'ye başvurmaları gayet normal. Bu yolu kullanmaları bence en güzeli. Kitap sevgisini kazandırmak için de sözlük ve imla kılavuzunu kullanmaları gerektiğine inanıyorum. Bir sözcügü ararken veya incelerken başka sözcüklerin de anlamını ögrenebilirler. Emek vererek bir şeyi elde etmenin hazzına varırlar." (E4)

"Sürekli olarak bu araçları kullanamıyorlar. Yani alışkanlık haline gelmiyor. Sözlük kullanmanın artması için ben sözlük aldırıyorum zorunlu olarak. Yazım kılavuzu ise sınıfa bir tane yeterli. Ancak ben sözcügü araştırırken telefon kullanıyorum. Öğrenciler de telefon kullanabilmeli ama bunun da sakıncaları olabiliyor tabi." (E6)

"Aslında bu konuda biraz aykırı düşünüyor olabilirim. Bence ögrencilere okulda, derste cep telefonu kullanmaları için (tabiki öğretmen kontrolünde) izin verilebilir. Böylece yazım kılavuzu ve sözlük hem daha hızlı kullanılmış olur hem de öğrenci sözlük taşıma derdinden kurtulur. Öğretmen olarak TDK'nın üç ciltlik sözlüklerine sahibim ancak okula getirme, derste kullanma durumum hiç olmadı. TDK'nın internetteki sözlüğü ve yazım kılavuzu zaten çoktan o lügatların yerini aldı." (E7)

K22 ise "Kitap olarak öneremiyorum. Çünkü TDK kuralları değiştirebiliyor, kitaplarda baskı hataları olabiliyor. tdk.gov.tr'ye yönlendiriyorum öğrencilerimi." diyerek diğer öğretmenlerden farklı olarak basılı sözlük ve kılavuz önermediğini vurgulamıştır.

Tablo 8.

Öğretmenlerin Türk Dil Kurumunun Kendi Web Sayfasındaki Yazım Kılavuzu Uygulamasını Kaldırarak Kelimelerin Yazımını, Anlamlarıyla Birlikte Güncel Türkçe Sözlük Başlığı Altında Vermesine Yönelik Görüşleri

\begin{tabular}{|c|c|c|c|}
\hline Kod & & $f$ & $\%$ \\
\hline Mantıklı ve daha işlevsel oldu. & & 23 & 57,50 \\
\hline Eski hali daha iyiydi, işlevselliğini kaybetti. & & 15 & 37,50 \\
\hline Hazırcılığa davetiye çıkarttı. & & 2 & 5,00 \\
\hline & Toplam & 40 & 100 \\
\hline
\end{tabular}

Tablo 8'de öğretmenlerin Türk Dil Kurumunun kendi web sayfasındaki Yazım Kılavuzu uygulamasını kaldırarak kelimelerin yazımını anlamlarıyla birlikte Güncel Türkçe Sözlük başlığı altında vermesi konusundaki görüşlerine ait dağılım yer almaktadır. Buna göre öğretmenlerin çoğu $(\% 57,50)$ bu uygulamanın daha mantıklı olduğunu ve bu durumun, uygulamanın işlevselliğini arttırdığını ifade etmiştir. Aşağıda buna yönelik bazı görüşlere yer verilmiştir: 
"Daha iyi bir durum olur. Böylece öğrenci kelimelerin yazımını öğrenirken, anlamına da göz atar." (K3)

"Genç nesil ve farklılaştırılmış eğitim modeli için güncel, anlaşılır buluyorum. (Pratik fayda, anlam bütünlüğünü artırır.) Konuşmaya istekli olur, diye düşünüyorum." (K10)

"Tek başlık altında toplaması zaman tasarrufu açısından iyi olmuş. Aynı zamanda öğrenci hem kelimenin yazımı hem anlamını derli toplu bir şekilde görebilmektedir." (K21)

"Bu uygulamanın daha faydalı olacağını düşünüyorum. Kelimenin bir özelliğine bakılırken önemli olan diğer özelliğine de bakılmış olur." (E9)

Türk Dil Kurumunun kendi web sayfasındaki Yazım Kılavuzu uygulamasını kaldırarak kelimelerin yazımını, anlamlarıyla birlikte Güncel Türkçe Sözlük başlığı altında vermesini işlevsel bulmayan bazı öğretmenlere ait görüşler ise şöyledir:

"Bir yandan güzel, anlamını da birlikte görmüş oluyorsunuz. Yazım Kılavuzu uygulamasının da şöyle bir avantajı vardı: Bir kelimenin içinde geçtiği diğer kelimeler, bütün birleşik kelimelerin yazımını da aynı anda görebiliyordunuz." (K1)

"Yazım Kılavuzu ve sözlügün ayrı olması daha işlevseldi. Daha rahat kullanılıyordu." (K30)

Öğrencinin bir kelimenin doğru yazımını bilmediği zaman Güncel Türkçe Sözlük'ten verimli bir şekilde yararlanamayacağını düşünen K12 konuya ilişkin düşüncesini "Kelimenin yazımını doğru bilmek gerekiyor. Öğrenci ararken sorun yaşayabiliyor. Öğrenciler uygulamanın karışık olduğunu, bu yüzden farklı ödev sitelerine baktıklarını söylediler." cümleleriyle ifade etmiştir.

K25 ise "Eski uygulamayı çok daha fazla beğeniyordum. Şu an ben bile aradığımı bulamıyorum. Öğrenciler için kılavuzluk yapıyordu. Şu an öğrenci açısından da çok işlevli olduğunu düşünmüyorum." diyerek bu konuda kendisinin de zorlandığına dikkat çekmiştir.

Tablo 9.

Öğretmenlerin Türkçe Dersi Öğretim Programı'nda (Ortaokul 5, 6, 7 ve 8. Sınıflar) Yazma Becerisine ilişkin Kazanımlara Yönelik Görüşleri

\begin{tabular}{|c|c|c|}
\hline Kod & $\mathrm{f}$ & $\%$ \\
\hline Yazma becerileri yeterli düzeyde değil. & 18 & 26,48 \\
\hline Yeterli ve olması gerektiği gibi. & 15 & 22,06 \\
\hline Yazma becerisine daha fazla vakit ayrılmalı. & 9 & 13,24 \\
\hline Müfredat yeterli fakat ders kitapları yazma becerisini desteklemiyor. & 6 & 8,82 \\
\hline Öğrenciler yazma konusunda çok isteksizler. & 5 & 7,35 \\
\hline $\begin{array}{l}\text { Yazma becerisi bir bütündür, diğer becerilerle birlikte verilmeli ve diğer derslerle } \\
\text { desteklenmeli. }\end{array}$ & 4 & 5,88 \\
\hline Geçen yıla göre müfredat iyileştirildi. & 4 & 5,88 \\
\hline Yazma becerisi yaratıcılığa yönelik olmalı. & 4 & 5,88 \\
\hline Okuma becerisi ile paralel olmalı. & 2 & 2,94 \\
\hline 5 ve 6. sınıflarda bu beceri yoğunlaştırılmalı. & 1 & 1,47 \\
\hline Toplam & 68 & 100 \\
\hline
\end{tabular}

Tablo 9'da öğretmenlerin Türkçe Dersi Öğretim Programı'nda (Ortaokul 5, 6, 7 ve 8. Sınıflar) yazma becerisine yönelik kazanımlar konusundaki görüşlerine ait dağıım yer almaktadır. Öğretmenlerin $\% 26,48$ 'i programdaki yazma becerilerine yönelik kazanımların yeterli düzeyde olmadığını söylemiştir. E4, bu konudaki düşüncelerini şu sözlerle dile getirmiştir:

"Yeterli değil. Mesleğe başladığımız ilk yıllarda Güzel Konuşma ve Yazma Dersi diye bir ders vardı. O ders haftada iki ders saati olduğu için her türlü faaliyeti rahatça gerçekleştirebiliyorduk. Türkçe dersini destekleyen ve başarıyı artıran bir dersti."

Programdaki yazma becerisine yönelik kazanımları yeterli bulmayan K9 ve E1 özellikle 5 ve 6 . sınıflarda yazma becerisine yönelik kazanımların arttırılması gerektiğini "Kazanımların yeterli olmadığını düşünüyorum. 5. ve 6. sınıflara yazı dersi yapılabilir." (K9); "Yazma becerisine dayalı kazanımlar 5. ve 6. sınıflarda yoğunlaşmalı." (E1) cümleleriyle dile getirmişlerdir. 
K24, Türkçe dersi öğretim programında yazma becerisine yönelik kazanımların yeterli ve olması gerektiği gibi olduğunu "Öğrenciler ile yazı yazmak hem eğlenceli hem de zor bir süreç. Onları önce yazı yazmaya motive etmek gerekiyor. Kompozisyon kelimesini duymak bile istemiyorlar. Ama yazmaya sevdalı ögrenciler de çıkmıyor değil. Yazı yazmak iyi bir bilgi birikimine bağlı. Açıkçası derslerde zorlanıyorum. Kazanımlar konusu da bana göre yeterli ve olması gerektiği gibi." cümleleriyle vurgulamıştır.

Yazma becerisine daha fazla vakit ayrılması gerektiği görüşünde olan K2, K16, K21 ve E8 de bu durumu ülkemizdeki sınav sistemiyle ilişkilendirerek konuyla ilgili görüşlerini şöyle dile getirmişlerdir:

"Bence okulda en önemli derslerden biri fakat ne kadar kazanımlar güzel olsa da iş uygulamaya döküldügünde bu ders rehberlik dersi imiş boş bir ders verin Matematik olsun anlayışıly hatta LGS'ye hazırlık gibi yapıldığında hiçbir kazanımın değeri kalmıyor." (K2)

"Öğrenciler sadece sınava yönelik hazırlandığından yazma becerilerine yeterli zaman ayrılamamaktadır." (K16)

"Ülkemizde sınav sisteminin varlığıyla ve bir öğrencinin başarısı sadece sınavdan yaptığı netlerle ölçüldügü için artık Türkçe dersinde okuma-yazma ve dinleme becerilerini layıkıyla öğrencilere kazandıramadığımızı düşünmekteyim." (K21)

"Yazma becerileri dersi öğrenciler için yararlıdır. LGS sınavları teste yönelttiği için öğrenciler tarafindan pek tercih görmüyor. Yazma becerisi kazanan öğrenciler duygu ve düşüncelerini daha iyi ifade ediyor." (E8)

K1 ve K7 Türkçe Dersi Öğretim Programı'nda yazma becerisine yönelik kazanımların öğrencilerin yazma becerilerini destekleme bakımından yeterli olduğunu ancak ders kitaplarının yazma becerilerini desteklemek konusunda yetersiz kaldığını ifade etmişlerdir. Öğretmenlere ait görüşler aşă̆ıda verilmiştir:

"Tüm sınıf düzeylerinde kazanımlar müfredata uygun olarak verilmiş fakat ders kitaplarındaki yazma etkinlikleri çok az ve güncel değil. Birkaç örnekle (çocukların ilgisini çekmeyen) geçiştirilmiştir. Ders kitaplarında yazma etkinliklerine daha fazla yer verilmeli." (K1)

"Türkçe Dersi Öğretim Programı'nda yazma becerisine yönelik kazanımlara yeterince yer verilmiş ancak ders kitaplarında bu kazanımları hayata geçirilebilecek yazma etkinliklerine yeterince yer verilmemiş. Ders kitaplarındaki yazma etkinlikleri tekrara düşüyor. Yani kitaplar yaratıcı yazma etkinlikleri açısından yetersiz. Öğrencilerin yazma becerilerini geliştirebilmek daha çok öğretmenlerin bu konudaki duyarlıı̆ıına ve donanımına bağlı." (K7)

Tablo 10.

Öğretmenlerin Türkçe Dersinde Yazım Kuralları Konusunu Işslerken Karşılaştıkları Sorunlara Yönelik Görüşleri

\begin{tabular}{lcc}
\hline Kod & $\mathrm{f}$ & $\%$ \\
\hline Kurallarla ilgili istisnaların olması. & 13 & 20,32 \\
Yazım kurallarının yeterince uygulanamaması. & 9 & 14,06 \\
Hataların ilkokuldan yerleşerek gelmesi. & 8 & 12,50 \\
Çok fazla kuralın olması. & 7 & 10,94 \\
Kuralların ezbere dayalı olmak zorunda olması. & 7 & 10,94 \\
Kuralların öğrencilere soyut gelmesi. & 5 & 7,81 \\
Öğrencilerin kitap okuma alışkanlıklarının olmaması. & 3 & 4,69 \\
Öğrencilerin konuştukları gibi yazma alıskanlıklarının olması. & 3 & 4,69 \\
Kurallara sadece Türkçe derslerinde uyulması. & 3 & 4,69 \\
Kaynak yetersizliğinin mevcut olması. & 2 & 3,12 \\
Yazı yazmadaki isteksizlik. & 2 & 3,12 \\
Sınıflarda teknolojik yetersizliklerin mevcut olması. & 1 & 1,56 \\
Türkçe derslerinin toplumca değersizleştirilmesi. & 1 & 1,56 \\
\hline & 64 & 100 \\
\hline
\end{tabular}


Tablo 10'da öğretmenlerin Türkçe dersinde yazım kuralları konusunu işlerken karşılaştıkları sorunlara yönelik görüşleri yer almaktadır. Bu bağlamda öğretmenlerin \%20,32'si yazım kurallarında bazı istisnaların olduğunu ve TDK'nin bu konuyla ilişkin sürekli değişiklik yaptığı için sıkıntı yaşadıklarını vurgulamışlardır. Katılımcılardan K21 ve K25’e ait görüşler aşağıda verilmiştir:

“TDK'nin sürekli yaptığı değişiklikler ve bazı kelimelerin yazımının neden o şekilde olduğunu açıklayamaması bizim ve öğrencilerin işini zorlaştırmaktadır. Öğrenci bu neden bitiş̧ik yazılır sorusunu sorduğunda "kalıp bu" cevabıyla tatmin olmamaktadır." (K21)

"Yazım kurallarını öğretirken işin mantığını kavratmakta zorlanıyorum. Doğru bilinen yanlışların yaygın olması işi zorlaştırıyor. Biz dahil kurallarla ilgili yeni şeyler öğreniyoruz. Netlik olmadığını düşünüyorum." (K25)

Yazım kurallarındaki istisnaların özellikle birleşik kelimelerde olduğunu dile getiren K7 ve E11'in konuyla ilgili görüşleri şöyledir:

"Yazım kuralları konusunu işlerken en zorlandığım nokta kurallarla ilgili pek çok istisnai durumun olmasıdır. Özellikle de birleşik sözcüklerin yazımında. Beni zorlayan bir diğer nokta da ögrencilerimin kuralları biliyor olmalarına rağmen yazılı anlatımlarında kuralları uygulama noktasında direnmeleri." (K7)

"Birleşik kelimelerin yazımında tam bir uyum yok. Birbirine yapı olarak benzeyen sözcüklerden bazıları bitişik bazıları ayrı yazılıyor. Neredeyse her sözcügün ezberlenmesi gerekiyor." (E11)

Bazı öğretmenler ise, yazım kurallarının öğrenciler tarafından yeterince anlaşılmasına ve bilinmesine rağmen uygulama boyutunda sorun yaşadıklarını belirtmişlerdir. Aşağıda buna ilişkin görüşlere yer verilmiştir:

"Kuralları işlerken nedense sorun yaşanmıyor. Fakat kuralın uygulanması sorun çıkarıyor. Öğrenciye sorduğumda kural tam olarak biliniyor, neden uygulayamadığı sorulunca suskunluk ile karşılaşıyorum. Çocuklar bir türlü uygulamıyor kuralları." (K3)

"Konu anlatılırken herhangi bir sorun yok, çok güzel anlaşılmış gibi duruyor. Fakat uygulamada teorik bilgiler kullanılamıyor öğrenciler tarafından." (K19)

K1 ve E6 ise ilkokuldan itibaren yerleşen hataların zor düzeltileceğine dikkat çekerek görüşlerini şu sözlerle ifade etmişlerdir:

"Çocukların yanlış bilgilerini düzeltmek gerçekten çok zor. Düzelttiğinizi düşünüyorsunuz bir bakıyorsunuz birkaç ders sonra tekrar aynı hatayı yapıyor. Hatalar ilkokuldan kalıplaşarak geliyor." (K1)

"Bazı öğrencilerin cümle sonunda nokta vb. işaret kullanmamaları, cümleye dahi büyük harfle başlamamaları; sonraki konuların öğretilmesini de etkiliyor. Bunları kazanmamış öğrencilere daha karmaşık kuralları ögretmek neredeyse imkânsız." (E6)

Türkçe dersinde yazım kuralları konusunu işlerken karşılaştıkları sorunlarla ilgili olarak çok fazla kuralın olmasına dikkat çeken K4 ve E7 konuyla ilgili görüşlerini şu sözlerle ifade etmişlerdir:

"Türkçe dersine toplumun bakış açısı! "Zaten Türkçe konuşuyoruz" denerek dersin değersizleştirilmesi. Kurallarda birlik olmaması, her kuralın bir istisnasının olması. Kuralların dönem dönem değişmesi. Kuralların çok ve dağınık olması. Kurallara sadece Türkçe dersi öğretmenlerinin uyması." (K4)

"Çok fazla kuralın olması ve öğrencilerin öğrettiğim kuralları çabucak unutması en sık karşılaştığım sorun." (E7)

Tablo 11.

Öğretmenlerin Türkçe Dersinde Yazım Kuralları Konusunu İşlerken Karşılaştıkları Sorunları Gidermek Amacılla Getirdikleri Öneriler

\begin{tabular}{lcc}
\hline Kod & $\mathrm{f}$ & $\%$ \\
\hline Yazım kurallarını bolca örnekle pekiştiriyorum. & 20 & 23,81 \\
Konuyla ilgili etkinlikler yapıyorum. & 16 & 19,05 \\
Yazma etkinlikleri yaptırıyorum. & 14 & 16,67 \\
Farkındalık yaratıyorum. & 11 & 13,10 \\
Sınıfa afişler asıyorum. & 8 & 9,52 \\
Kısa videolar izletiyorum. & 4 & 4,76 \\
\hline
\end{tabular}




\begin{tabular}{|c|c|c|c|}
\hline Sözlük çalışması yaptırıyorum. & & 4 & 4,76 \\
\hline Konuyu hikayeleştiriyorum. & & 3 & 3,57 \\
\hline Örnek olmaya çalışıyorum. & & 3 & 3,57 \\
\hline Kitap okumalarını istiyorum. & & 1 & 1,19 \\
\hline & Toplam & 84 & 100 \\
\hline
\end{tabular}

Tablo 11 'de öğretmenlerin Türkçe dersinde yazım kuralları konusunu işlerken karşılaştıkları sorunları gidermek amacıyla getirdikleri öneriler yer almaktadır. Bu bağlamda, öğretmenlerin \%23,81'i yazım kurallarını bolca örnekle pekiştirdiklerini ifade etmişlerdir. Örnekleri konu tekrarı ile pekiştirdiklerini vurgulayan K6 ve K24'e ait görüşler aşağıda sunulmuştur:

"Türkçe dersinde yazım kuralları konusunu işlerken karşılaştığımız sorunları gidermek için bolca tekrar yapıyoruz. Her türlü metinde, yazılan kompozisyonlarda yapılan hataları birlikte düzeltiyoruz." (K6)

"Bol bol tekrar yapıyorum. Öğrencinin farklı tarzda farklı yazarlarla tanışmasını sağlıyorum. Sınıfın çeşitli yerlerine afişler asıyorum. Özellikle medya ile ilişkilendirip ya da dersi sosyal hayatları ile ilişkilendirip dikkat çekmeye çalışıyorum." (K24)

K18 "Bolca kitap okumalarını istiyorum. Verdiğim metindeki yazım hatalarını buluyorlar. Kuralları ezberlemek olmaz, uygulamak gereklidir. Oyunlarla, EBA'dan faydalanarak sorunları gidermeye çalışıyorum. Yazım hatalarıyla ilgili araştırmalar yapmalarını istiyorum."; K32 "Dil bayramında "Tişört Boyama" etkinliği yaptırıyorum. Bu etkinlikle birlikte "Türkçesi Varken" adı altında kelimelerin Türkçe karşııılarını ve düzgün yazımını buluyorlar. Ya da bir kelime söylüyorum. Tüm sınıf yazıyor. Doğru yazanlar puan alıyor."; E9 "Sılk sık uygulamalar ve örnek sorular yaptırıyorum. Değerlendirme yapıyorum. Yapılan etkinliklerde öğrencilerin birbirlerini değerlendirmesini istiyorum. Öğrencilerin yaptıkları hatalar üzerinde duruyorum." cümleleriyle yazım kurallarına yönelik çeşitli etkinlikler yaptırarak sorunların üstesinden gelmeye çalıştıklarını vurgulamışlardır.

Türkçe dersinde yazım kuralları konusunu işlerken karşılaştığı sorunları gidermek için konuyla ilgili farkındalık yarattığını ifade eden K5 konuyla ilgili görüşlerini şu sözlerle dile getirmiştir:

"Doğrusuna ulaştırıyorum. Neden yanlış yaptığını gösterip, farkındalık oluşturuyorum. Örnek olmaya çalışıyorum. Türkçemizin önemini anlatıp; böyle yapılan yanlışların Türkçeyi yaraladığını anlatıyorum. Türkçeyi sevdirmek... vb."

K7 ve K21 ise yazım kuralları konusuyla ilgili sınıflara afiş asarak öğrencilerin konuyu öğrenmelerine görsel yönden de destek olduklarını şu sözlerle dile getirmişlerdir:

"Yazım kurallarını daha kalııı hale getirebilmek için sınıf panolarımıza "Doğru Yazalım" köşeleri yapıyoruz. Bu panolarımızda müfredatımız doğrultusunda yazım kurallarını görsel ve renkli anlatımlarla işliyoruz. Bolca yazma etkinliği yapıyoruz ve eğitsel oyunlar oynayarak yazım kurallarını kalıcı hale getirmeye çalışıyoruz." (K7)

"Genelde kurallara dayandırılan yazımlarda öğrenciler sıkıntı yaşamamaktadır. En çok "Yazımı Karıştııılan Sözcükler" konusunda sıkıntı olmaktadır. Bu kelimeleri çıkartıp koridor panosuna asıyorum ki gelip giderken göz aşinalığıyla zihinlerine yerleştirsinler diye." (K21)

K12 "Konular arasında bağlantı kurarak, dikkat çekiyorum. Zaman zaman sözlü anlamında bilgi yokluyorum. Panolara yazım kurallarını hatırlatıcı görsel asıyorum. Etkinlik yapıyorum. Soru çözümünde (sınavda çıkacak) diyerek ilgi çekmeye çalısııorum. Yazım kurallarının önemini hatırlatan ve belirten kısa videolar izletiyorum." diyerek farklı yöntemlerle birlikte konuyla ilgili kısa videolar da izlettiğini dile getirmiştir.

Hikâyeleştirme yöntemini kullanarak yazım kurallarını anlatmaya çalıştığına dikkat çeken K1 bu konuya ilişkin görüşlerini "Hikâyeleştiriyorum. Örneğin "şey" kelimesinin geçimsiz olduğunu, kimseyle anlaşamadığını bu nedenle hep yalnız, hep ayrı yazıldığını belirtiyorum. Kelimelerin nereden geldiği hakkında bilgi veriyorum. Sık sık yazımı yanlış olan kelimeyi vurgulu bir şekilde söylüyorum. Bol bol uygulama yaptırıp yanlışları birlikte değerlendiriyoruz çocuklarla." cümleleriyle ifade etmiştir. 
Tablo 12.

Öğretmenlerin Türkçe Dersinde Yazım Kuralları Konusunun Öğrencilere Daha Iyi Kazandırılabilmesi Için Getirdikleri Öneriler

\begin{tabular}{lcc}
\hline Kod & $\mathrm{f}$ & $\%$ \\
\hline Yazma etkinlikleri bol bol yaptırılmalı ve oyunlarla desteklenmeli. & 16 & 21,62 \\
İlkokulda yazma ve noktalama çalışmalarına ağırlık verilmeli. & 9 & 12,16 \\
Öğrenciye okuma alışkanlığı kazandırılmalı. & 6 & 8,11 \\
Öğrenciler kuralları ilkokulda iyi öğrenmiş olmalı. & 5 & 6,76 \\
Kurallar netleştirilmeli. & 4 & 5,41 \\
Kurallar örneklerle içselleştirilmeli. & 4 & 5,41 \\
Kuralların öğretiminde teknolojiden yararlanılmalı. & 4 & 5,41 \\
Dikte dersleri olmalı. & 4 & 5,41 \\
Farklı okullardan öğretmenlerle ortak yazma etkinlikleri yapılmalı. & 4 & 5,41 \\
Öğrencilerin en çok vakit geçırdiği yerlere konuyla ilgili afişler asılmalı. & 3 & 4,05 \\
Kitaptaki etkinlikler geliştirilmeli. & 3 & 4,05 \\
Yazım kılavuzu ve sözlük kullanımı arttırılmalı. & 2 & 2,70 \\
Diğer branşlarca da desteklenmeli. & 2 & 2,70 \\
Öğrenci yanlış yazınca düzeltilmeli. & 2 & 2,70 \\
Üniversiteden akademisyenler davet edilmeli. & 1 & 1,35 \\
Yazarlarla söyleşi yapıımalı. & 1 & 1,35 \\
Konular bölünmeli. & 1 & 1,35 \\
Günlük hayatta uygulanmalı. & 1 & 1,35 \\
TDK sitesinde uygulamalar olmalı. & 1 & 1,35 \\
Türkçe ek kaynak kitapları özel basılmalı. & 1 & 1,35 \\
\hline & 74 & 100 \\
\hline
\end{tabular}

Tablo 12'de öğretmenlerin Türkçe dersinde yazım kuralları konusunun öğrencilere daha iyi kazandırılabilmesi için getirdikleri öneriler yer almaktadır. Öğretmenlerden \%21,62'si yazım kuralları konusunun öğrencilere daha iyi kavratılabilmesi için yazma etkinliklerinin bol yapılması ve gerektiğinde oyunlarla desteklenmesi gerektiğini vurgulamıştır. K30, K32 ve E2 konuya ilişkin görüşlerini şu sözlerle dile getirmişlerdir:

"Derslerde yazma çalışmalarına ağırlık verilebilir. Doğru kitap seçimiyle okuma alışkanlıkları desteklenmeli. Çeşitli videolar hazırlanmalı, güncel örneklere ağırlık verilmeli. Bu konuyla ilgili oyunlar tasarlanmalı ve oynatılmalı." (K30)

"Öğrencilere daha fazla yazma becerisini geliştirici etkinlikler yapılmalı. Yanlış yazım yaptığında mutlaka dönüt ve düzeltme yapılmalı. Yazım kuralları daha çok oyun ve etkinlikle işlenmeli." (K32)

"Bence bolca yazı çalışması, uygulama yaptırılabilir. Tabii ki yazma isteklerini artırmak şartıyla. Ayrıca bu yönde test ve egzersiz yaptırılabilir." (E2)

K1 ise yazım kuralları konusunun öğrencilere daha iyi kazandırılabilmesinin ancak yazım ve noktalama çalışmalarına ağırlık verilmesiyle mümkün olduğunu şu cümlelerle dile getirmektedir:

"Ilkokul Türkçe müfredatının sadece okuma, anlama, yazım, noktalamadan ibaret olması gerektiğini düşünüyorum. Dil bilgisi konularının ilkokul müfredatından çıkarılması gerekmektedir. ilkokulda yazma ve noktalama çalışmalarına ağırlık verilmeli. Ortaokulda da bu ağırlık sürdürülerek bolca yazma etkinlikleri ile pekiştirilmeli ve hatalar anında düzeltilmelidir."

K7 "Yazım kurallarının öğrencilere daha iyi kazandırılması için öncelikle düzenli okuma alışkanlığının kazandırılması önemli. Daha fazla yazma etkinliği yapılması da yani yazma becerilerine yönelik kazanımların diğer kazanımların gölgesinde kalmaması da çok önemli. Türkçe dersi dışında okul içerisinde öğrencilerin en çok vakit geçirdiği alanlarda yazım kuralları ile ilgili görsellerin, afişlerin, duvar yazılarının yer alması da etkili olacaktır." diyerek yazım kurallarının okuma yoluyla kazandırılabileceğini ifade etmiştir. 
Yazım kurallarının öğrencilere ilkokulda eksiksiz olarak kazandırılması gerektiğini ifade eden K22'ye ait görüş şöyledir:

"Bu konunun ilkokulun temel amaçları olması gerekir. Öğrenci 5. sınıfa geldiğinde hâlâ cümleye büyük harfle başlayamıyorsa bir sıkıntı vardır." (K22)

K4 "Kurallar konusunda birlik ve sınav sorularında istikrar olmalıdır. Sürekli kural değişmemelidir. Bilgiye ulaşım kolaylaştırılmalıdır. Sınavlarda yazım kurallarının ağırlığı arttırılmalıdır." ve K6 “Öncelikle TDK'nin belirli bir sistemi uygulaması. Bazı kelimeler bitişik, bazı kelimeler ayrıken bir bakmışız değişiveriyor. Bizler de bu duruma ayak uydurmakta sıkıntı yaşıyoruz. Neden yeşilzeytin bitişik, siyah zeytin ayrı yazılıyor açıklayabilmiş değilim." cümleleriyle öncelikle yazım kurallarının netleştirilmesi ve bir mantık çerçevesinde açıklanabilir olması gerektiğini vurgulamışlardır.

Türkçe dersinde dikte çalışmaları aracılığıyla yazım kuralları konusunun öğrencilere daha iyi kazandırılabileceğine dikkat çeken K14 görüşlerini şu sözlerle açıklamaktadır:

"Ayrı bir ders saati ayrılarak düzenli dikte yapılmalı. Diğer branşöğretmenlerinin de yazım kurallarına ve yazı güzelliğine dikkat etmeleri gerekmekte."

Farklı okullardan öğretmenlerle ortak yazma etkinliklerinin yapılmasını öneren K10 ve K12 bu konudaki düşüncelerini şöyle dile getirmişlerdir:

"Türkçe ek kaynak kitapların sadece dil bilgisi ve yazım kuralları test soruları, alıştırmalar olarak özel basılması. Yazım kurallarıyla ilgili okullarda yarışmaların düzenlenmesi teşvik amaçı." (K10)

"Üniversiteden akademisyenler davet edilerek, ögrencilerle beraber bir etkinlik yapılabilir. Yazarlarla söyleşi yapılabilir. Farklı okullardan öğretmenlerle iş birliği yapılıp, öğrencilerle etkinlik yapılabilir. Yazmanın önemini hatırlatıcı, milli ve manevi değerlerle pekiştirme yapılabilir." (K12)

Tablo 13.

Öğretmenlerin Yarı Yapılandırılmış Görüşme Formunda Yer Alan Soruların Dışında Eklemek İstedikleri Görüşler

\begin{tabular}{lc}
\hline Eklemek istedikleriniz varsa lütfen yazınız. & Katılımcl \\
\hline Kütüphanelerde Dil ve Türkçe kitapları güncel olmalı. & $\mathrm{K} 10$ \\
Okuma Becerileri hakkında kitaplar yazılıın. & $\mathrm{K} 10$ \\
Türkçe Öğretim Programı hafifletilsin. & $\mathrm{K} 22$ \\
Güzel Konuşma ve Yazma dersi zorunlu olsun. & $\mathrm{E} 4$ \\
Her derste dikte yapılsın. & $\mathrm{K} 2$ \\
Ders kitaplarındaki metinler özenli seçilsin. & $\mathrm{E} 1$ \\
\hline
\end{tabular}

Tablo 13'te öğretmenlerin yarı yapılandırılmış görüşme formunda yer alan sorulara verdikleri cevapların dışında eklemek istedikleri görüşlere ait bilgiler yer almaktadır. Bu bağlamda altı öğretmen bu doğrultuda görüş bildirmiştir. Aşağıda, bu görüşlerden bazılarına yer verilmiştir.

"Türkçe programı hafifletilsin. Okuma sevgisi ve alışkanlığı, kompozisyon becerileri, düşünme ve ifade etme becerileri, noktalama-yazım kuralları, temel dil bilgisi kuralları verilsin yeter. Gerisini biz yaparız." (K22)

"Güzel Konuşma ve Yazma dersi zorunlu ders olarak haftada en az iki saat olmak üzere ortaokulların en az iki sınıfında (5. sınıflar ve 6. sınıflar) okutulmalıdır." (E4)

\section{Tartışma ve Sonuç}

Bu çalışmada, Türkçe öğretmenlerinin yazımı karıştırılan kelimelere yönelik görüşlerinin belirlenmesi amaçlanmıştır. Bu amaç doğrultusunda elde edilen sonuçlar aşağıda sıralanarak benzer çalışmalarla tartışıımışıır.

Yapılan görüşmeler sonucunda Türkçe öğretmenlerinin, öğrencilerin sırasıyla \%31,43 ile yazımı karıştırılan kelimeler, \%28,57 ile birleşik kelimelerin yazımı, \%20 ile büyük harflerin yazımı, \%8,57 ile sayıların yazımı, \%8,57 ile ek ve ikilemelerin yazımı, \%2,86 ile kısaltmaların yazımı konusunda zorlandıklarını düşündükleri sonucuna ulaşılmıştır. Başka bir ifadeyle, Türkçe öğretmenleri, 
öğrencilerin en az kısaltmaların, ek ve ikilemelerin, sayıların yazımında hata yaptıklarını düşünmektedir. Bu bulgu, Akkaya (2013) tarafından yapılan "6. Sınıf Öğrencilerinin Yazım Yanlışları Sıklığı ve Yazım Yanlışlarının Nedenlerine ílişkin Öğretmen Görüşleri" adlı çalışmasındaki bulgularla örtüşmektedir. Buna göre öğrenciler, kısaltmaların yazımı konusunda hiç hata yapmazken ikilemelerin yazımında $\% 0,07$ oranında, sayıların yazımında ise $\% 0,48$ oranında yanlış yapmışlardır.

Türkçe öğretmenlerinin \%14,67'si öğrencilerin kitap okumamasını, kelimelerin öğrenciler tarafından yanlış yazıımasının temel sebebi olarak görmektedir. Batur, Erkek, Ertan Özen ve Ellialtı (2017: 63) da öğretmenlerin bu görüşünü destekler nitelikte "Dil kurallarının yeterince ya da zamanında (doğru yaşta) öğretilememesi, dil kullanımına toplumsal olarak yeterince önem verilmemesi, anlık yazılı iletişimde dil kurallarının gözetilmemesi gibi birçok sebep yazılı anlatım hatalarına ve anlatım bozukluklarına neden olabilir. Ancak okuyan insanların bu olumsuzluklarla baş edebilmesi diğerlerine göre daha kolaydır" diyerek çok kitap okuyan kişilerin daha az yazım yanlışı yapacağını düşündüklerini dile getirmişlerdir.

Türkçe öğretmenlerinin \%10,67'si ise yazım kurallarının sürekli değişmesini, kelimelerin öğrenciler tarafından yanlış yazılmasının temel sebebi olarak görmektedir. Akdağ (2020) "Türkçe Yazım Kılavuzları ve Yazımda Sağlanamayan Birlik" adlı çalışmasında yazım kılavuzlarının yazımında sürekli değişikliklere gidilmesinin Türkçenin eğitimi ve öğretiminde büyük sorunlar oluşturduğunu, yazımı değişen kelimelerin hem konuşma hem de yazmada karışıklıklara neden olduğunu dile getirmiştir. Bu bağlamda sonuçların örtüştüğü görülmektedir.

Türkçe öğretmenlerinin \%28,73'ü kitle iletişim araçlarında kelimelerin çok özensiz bir şekilde yazıldığını ve \%21,28'i kitle iletişim araçlarının yazım yanlışlarını kalıcı hâle getirdiğini belirtmiştir. Karahisar'ın 2013 yılında yaptığı "Dijital Nesil, Dijital Iletişim ve Dijitalleşen (!) Türkçe" adlı çalışma da bu durumu destekler niteliktedir. Karahisar (2013: 76) bu durumu "dilin kullanımını doğrudan etkileyen bir başka öge de medyadır. Televizyon izleme alışkanlığının yüksek olduğu ülkemizde özellikle çocuklar dilin yanlış kullanımı ile karşı karşıya kalmaktadır. Ekrandaki dilbilgisi kurallarına uymayan yazılar çocuklar tarafından fark edilememekte ve doğruymuş gibi algılanmaktadır" cümleleriyle vurgulamaktadır.

Maden ve Maden (2018) "Türkçe Öğretmeni Adaylarının Elektronik Sözlük ve Yazım Kılavuzu Kullanma Alışkanlıkları" adlı çalışmalarında elektronik sözlük ve yazım kılavuzu kullanmanın önemine değinmişlerdir. "Elektronik ortamlardaki sözlük ve yazım kılavuzlarından gerek genel ağ üzerinden gerekse mobil cihaz uygulamalarından yararlanma bilgi çağında, doğal ve gerekli bir durumdur. Bahsedilen elektronik kaynaklar dijital ortamın ve genel ağın kolay erişim, güncellik ve görsel-işitsel diğer özellikleri ile her geçen gün artmakta ve yenilenmektedir" (Maden ve Maden, 2018: 382). Bu çalışmada da Türkçe öğretmenlerinin \%42,62'si bir kelimenin yazımıyla ilgili tereddüte düştüklerinde TDK'nin resmi internet sayfasındaki elektronik sözlükten yararlandıklarını ifade etmişlerdir. Bu bağlamda elektronik sözlük ve yazım kılavuzu kullanımının gün geçtikçe daha da benimsendiği görülmektedir.

Türkçe öğretmenlerinin $\% 77,78^{\prime}$ i öğrencilerin mutlaka Yazım Kılavuzu/ Sözlük kullanmaları gerektiğini ifade ederken öğretmenlerin $\% 8,89^{\prime}$ u bu görüşe katılmakla birlikte bunun için internetten de yararlanılabileceğini dile getirmiştir.

Öğretmenlerin \%57,5'i Türk Dil Kurumunun kendi web sayfasındaki Yazım Kılavuzu uygulamasını kaldırarak kelimelerin yazımını anlamlarıyla birlikte Güncel Türkçe Sözlük başlığı altında vermesini çok mantıklı bulduklarını ve bu durumun uygulamanın işlevselliğini artırdığını belirtmişlerdir.

Türkçe Dersi Öğretim Programında (Ortaokul 5, 6, 7 ve 8. Sınıflar) yazma becerisine yönelik kazanımların yeterli düzeyde olmadığını ifade eden öğretmenlerinin \%26,48'i özellikle 5 ve 6 . sınıflarda yazma becerisine yönelik kazanımların artırılması gerektiğini söylemişlerdir. 2019 Türkçe Dersi Öğretim Programı yazma becerisine yönelik kazanımlar açısından incelendiğinde beşinci sınıfta 16, altıncı sınıfta 14, yedinci sınıfta 17 ve sekizinci sınıfta 20 kazanımın yer aldığı görülmektedir (MEB, 2019). 4+4+4'lük eğitim sistemine geçildikten sonra Türkçe dersine yönelik hazırlanan ilk program olan 2015 Türkçe Dersi Öğretim Programı incelendiğinde ise yazma becerisine yönelik hem ana hem de alt kazanımların yer aldığı görülmektedir. Sınıflara göre dağııım şöyledir: 5. sınıf 13 ana + 16 alt kazanım, 6. sınıf 13 ana + 16 alt kazanım, 7. sınıf 11 ana +18 alt kazanım, 8. sınıf 12 ana +18 alt kazanım (MEB, 2015). Bu 
bağlamda ana ve alt kazanımlar bir bütün olarak değerlendirildiğinde 2019 Türkçe Dersi Öğretim Programında yazma becerisine yönelik olan kazanımların 2015 Türkçe Dersi Öğretim Programındaki kazanımlara oranla oldukça az olduğu anlaşılmaktadır. Bununla birlikte 2019 Türkçe Dersi Öğretim Programında yazım ve noktalama konularına yönelik öğretiminin 1-5. sınıflarda tamamlanması gerektiği; 6, 7 ve 8 . sınıflara yönelik yazım kuralları ve noktalama işaretlerinin kullanımıyla ilgili "Yazdıklarını düzenler." kazanımı dışında ayrı bir kazanımın yer almadığı görülürken yazım kurallarının uygulanması ve noktalama işaretlerinin doğru kullanılması konusunda gerektiği kadar yönlendirme yapılmadığı da tespit edilmiştir. Bu durum, öğretmenlerin görüşlerini destekler niteliktedir.

Türkçe öğretmenleri, yazım kuralları konusunu işlerken karşılaştıkları sorunları gidermek amacıyla öneriler getirmiştir. Öğretmenlerden $\% 23,81^{\prime} \mathrm{i}$ yazım kurallarını bolca örnekle pekiştirdiklerini ifade ederken \%19,05'i konuyla ilgili etkinlikler yaptırdıklarını söylemişlerdir. Öğretmenler, verdikleri metinlerdeki yazım yanlışlarını buldurduklarını, EBA'dan faydalanarak oyunlar oynattıklarını, Türk Dil Bayramı'nda "Tişört Boyama" etkinlikleri yaptırdıklarını, "Türkçesi Varken" adlı etkinlikle kelimelerin Türkçe karşııklarını ve doğru yazımını buldurduklarını, yapılan etkinliklerde öğrencilerin birbirlerini değerlendirmesini isteyip akran değerlendirmesi gibi metotlardan faydalandıklarını dile getirmişlerdir. Bu durum, konunun öğretimine ilişkin farklı metotlar kullanmanın, konunun anlaşımasının önündeki engelleri kaldırmasıyla birlikte öğrencilere uygulama yapma imkânını da sağlaması nedeniyle öğrenmeyi kalıcı hâle getirecektir.

Türkçe öğretmenlerinin \%21,62'si yazım kuralları konusunu öğrencilere daha iyi kavratabilmek için yazma etkinliklerinin bol yapılması ve oyunlarla desteklenmesi gerektiğini belirtmişlerdir. Batur ve Özdil (2018) tarafından yapılan "Yazım Yanlışlarının Düzeltilmesine Yönelik Bir Öneri: Manas Oyunu" adlı çalışmada, araştırmacılar tarafından geliştirilen Manas Oyunu'nun yazım yanlışlarını düzeltmede etkili olduğu, öğrencilerin hazırlık ve uygulama kâğıtları incelendiğinde daha az yanlış yapmış oldukları, telaffuzlarında ve yazılı ifadelerinde olumlu yönde değişmeler olduğu tespit edilmiştir. Bu durum, Türkçe öğretmenlerinin yazımı karıştırılan kelimelerin öğretiminde etkinlik ve materyal kullanmanın, konunun öğretiminde kalıcılığı arttırdığı görüşünü desteklemektedir.

Sonuçlardan hareketle getirilebilecek öneriler şöyledir:

- Konuşma dili ve yazı dili arasındaki farklılıklardan kaynaklanan yazımı karıştırılan kelimeler konusunda kesin ve değişmez kurallar getirilmelidir. Bunun için kelimelerin yazımları netleştirilmeli ve bu yazımlar bir mantık çerçevesinde açıklanabilir olmalıdır.

- İmla, ezberlenmesi gereken kurallar bütünü olmaktan çıkarılıp bu kuralların uygulanması çeşitli etkinlik ve materyallerle desteklenmelidir.

- Teknolojik gelişmeler, hayatımızın birçok alanında olduğu gibi bilgi edinme şekilleri üzerinde de etkili olmuştur. Bu durum kelimelerin anlamını ve yazııışlarını öğrenmek için elektronik ortamdan yararlanılmasının önünü açmıştır. Bu nedenle Türkçe öğretmenleri teknolojiyi doğru ve faydalı kullanma alıskanlıklarına sahip olmalı, öğrencilerin teknolojik kaynakları etkin biçimde kullanmalarını desteklemelidir.

- Televizyon, dergi, gazete vb. kitle iletişim araçları günlük hayatımızda önemli bir yere sahiptir. Bu araçlarda özel isimlerin küçük yazılması, kısaltmalara getirilen eklerin yanlış yazııması, noktalama işaretlerinin yanlış kullanılması vb. hatalar, dil üzerinde olumsuz etkilere neden olmaktadır. Kitle iletişim araçlarına yapılan denetimlerin sıklaştırılması, ilgili hataların önüne geçebilme konusunda etkili olabilir.

\section{Araştırma ve Yayın Etiği}

Bu çalışmada "Yükseköğretim Kurumları Bilimsel Araştırma ve Yayın Etiği Yönergesi" kapsamında uyulması belirtilen tüm kurallara uyulmuştur. Yönergenin ikinci bölümü olan "Bilimsel Araştırma ve Yayın Etiğine Aykırı Eylemler" başlığı altında belirtilen eylemlerden hiçbiri gerçekleştirilmemiştir.

\section{Etik Kurul Izni}

Kurul adı = Çanakkale Onsekiz Mart Üniversitesi Sosyal Bilimler ve Eğitim Bilimleri Etik Kurulu Karar tarihi $=27.11 .2019$ 
Toplantı sayısı $=10$

\section{Yazarların Katkı Oranı}

Makalenin hazırlanmasında 1. yazar \%50, 2. yazar \%50 oranında katkı sağlamıştır.

\section{Çıkar Çatışması}

Bu araştırmada çıkar çatışması teşkil edebilecek herhangi bir durum ya da ilişki bulunmamaktadır.

\section{Destek ve Teşekkür}

Bu araştırma, Çanakkale Onsekiz Mart Üniversitesi Bilimsel Araştırma Projeleri Koordinasyon Birimince Desteklenmiştir. Proje Kodu: SYL-2020-3168. Çanakkale Onsekiz Mart Üniversitesi Bilimsel Araştırma Projeleri Koordinasyon Birimi’ne destekleri için teşekkür ederiz.

\section{Kaynaklar}

Akdağ, E. (2020). Türkçe yazım kılavuzları ve yazımda sağlanamayan birlik. PESA International Journal of Social Studies, 6(1), 69-81. DOI: 10.25272/j.2149-8385.2020.6.1.06.

Akkaya, A. (2013). 6. sınıf öğrencilerinin yazım yanlışları sıklığı ve yazım yanlışlarının nedenlerine ilişkin öğretmen görüşleri. Turkish Studies- International Periodical For The Languages, Literature and History of Turkish or Turkic, 8(4), 33-52. DOI: 10.7827/TurkishStudies.4989.

Balyemez, S. (2012). TDK İmlâ/ Yazım kılavuzlarının kısaltmalar bölümleri üzerine bir değerlendirme. Bartın Üniversitesi Eğitim Fakültesi Dergisi, 1(1), 41-57.

Batur, Z., Erkek, G., Ertan Özen, N. ve Ellialtı, M. (2017). Yazılı anlatım yanlışlarının/ hatalarının öğrenim düzeylerine göre incelenmesi. International Journal of Language Academy, 5(17), 61-73. DOI: 10.18033/ijla.3613.

Batur, Z. ve Özdil, Ş. (2018). Yazım yanlışlarının düzeltilmesine yönelik bir öneri: Manas oyunu. Araştırma ve Deneyim Dergisi (ADEDER), 3(2), 118-129.

Büyüköztürk, Ş., Kılıç Çakmak, E., Akgün, Ö. E., Karadeniz, Ş. ve Demirel, F. (2020). Eğitimde bilimsel araştırma yöntemleri (29. Baskı). Ankara: Pegem Akademi.

Çiftçi, B. (2020). Türkçe öğretmeni ve adaylarının yazımı karıştırılan kelimelere yönelik görüşleri (Yayımlanmamış yüksek lisans tezi). Çanakkale Onsekiz Mart Üniversitesi Lisansüstü Eğitim Enstitüsü, Çanakkale.

Demir, C. (2018). Okullarımızda yazım eğitimi ve sorunları üzerine. Afyon Kocatepe Üniversitesi Sosyal Bilimler Dergisi, 20(3), 121-135. DOI: 10.32709/akusosbil.484300.

Gönenç, E. Ö. (2007). İletişimin tarihsel süreci. İstanbul Üniversitesi Iletişim Fakültesi Dergisi, 28, 87102.

Gürbüz, S. ve Şahin, F. (2018). Sosyal bilimlerde araştırma yöntemleri (5. Baskı). Ankara: Seçkin Yayıncılık.

Karahisar, T. (2013). Dijital nesil, dijital iletişim ve dijitalleşen (!) Türkçe. AJIT-e Online Academic Journal of Information Technology, 4(12), 71-83. DOI: 10.5824/1309-1581.2013.3.006.x.

Karasar, N. (2005). Bilimsel araştırma yöntemi (15. Baskı). Ankara: Nobel Yayın Dağıım.

Karatay, H. (2011). 4+1 planlı yazma ve değerlendirme modelinin öğretmen adaylarının yazılı anlatım tutumlarını ve yazma becerilerini geliştirmeye etkisi. Turkish Studies- International Periodical For The Languages, Literature and History of Turkish or Turkic, 6(3), 1029-1047. DOI: 10.7827/TurkishStudies.2622.

Kurudayığlu, M. ve Çimen, L. (2020). Yabancı dil olarak Türkçe öğrenen öğrencilerin akademik yazılarında etkileşimli üstsöylem belirleyicilerinin kullanımı. OPUS Uluslararası Toplum Araştırmaları Dergisi, 16(31), 3899-3923. DOI: 10.26466/opus.771950.

Maden, S. ve Maden, A. (2018). Türkçe öğretmeni adaylarının elektronik sözlük ve yazım kılavuzu kullanma alışkanlıkları. Kırıkkale Üniversitesi Sosyal Bilimler Dergisi (KÜSBD), 8(2), 377-395.

MEB (2015). Türkçe dersi (1-8. sınıflar) öğretim programı. Ankara: T.C. Millî Eğitim Bakanlığı Talim ve Terbiye Kurulu Başkanlığı. 
MEB (2019). Türkçe dersi öğretim programı (ilkokul ve ortaokul 1, 2, 3, 4, 5, 6, 7 ve 8. sınıflar). Ankara: T.C. Millî Eğitim Bakanlığı.

Örge Yaşar, F. (2020). Konuşma türleri. M. N. Kardaş (Ed.)., Konuşma eğitimi içinde (ss. 201-218). Ankara: Pegem Akademi.

Örge Yaşar, F. ve Çiftçi, B. (2020). Türkçe eğitimi anabilim dalı öğrencilerinin yazımı karıştırılan kelimelere yönelik yeterlilikleri. E. Yağmur Şahin (Ed.), Türkçe eğitimi ve Türk edebiyatı araştırmaları içinde (ss. 265-286). Çanakkale: Paradigma Akademi.

Resmî Gazete (2 Kasım 2011). Atatürk Kültür, Dil ve Tarih Yüksek Kurumu Teşkilat ve Görevleri Hakkında Kanun Hükmünde Kararname. Erişim Adresi: https://www.resmigazete.gov.tr/eskiler/2011/11/20111102M1-4.htm

Sancak, Ş., Alver, M. ve Durukan, E. (2009). Türk Dil Kurumunun imlâ/ yazım kılavuzlarındaki değişiklikler üzerine bir inceleme. Atatürk Üniversitesi Sosyal Bilimler Enstitüsü Dergisi, 13(1), 117-130.

Şahin, Ç. (2010). Verilerin analizi. R. Y. Kıncal (Ed.), Bilimsel araştırma yöntemleri içinde (ss. 182-217). Ankara: Nobel Yayın Dağıtım.

TDK (1941). Imlâ kılavuzu. İstanbul: Cumhuriyet Basımevi.

TDK (1960). Imlâ kılavuzu. Türk Dil Kurumu Yayınları Sayı: 184, Ankara: Türk Tarih Kurumu Basımevi.

TDK (1965). Yeni imlâ kılavuzu. Türk Dil Kurumu Yayınları Sayı: 235, Ankara: Türk Tarih Kurumu Basımevi.

TDK (1988). Imlâ kılavuzu. Atatürk Kültür, Dil ve Tarih Yüksek Kurumu Türk Dil Kurumu Yayınları: 525, Ankara: Türk Tarih Kurumu Basım Evi.

TDK (2005). Yazım kılavuzu. Ankara: Türk Dil Kurumu.

TDK (2012). Yazım kılavuzu. Atatürk Kültür, Dil ve Tarih Yüksek Kurumu Türk Dil Kurumu Yayınları: 859, Ankara: Türk Dil Kurumu.

TDK. (2021). Güncel Türkçe Sözlük. Erişim adresi: sozluk.gov.tr

Türnüklü, A. (2000). Eğitimbilim araştırmalarında etkin olarak kullanılabilecek nitel bir araştırma tekniği: Görüşme. Kuram ve Uygulamada Eğitim Yönetimi, 6(24), 543-559.

Walter, M. (2020). The nature of social science research. Oxford University Press. Erişim adresi: http://lib.oup.com.au/he/study_skills/samples/walter_socialresearch3e_sample.pdf (Erişim Tarihi: 09.04.2020)

Yıldırım, A. ve Şimşek, H. (2018). Sosyal bilimlerde nitel araştırma yöntemleri (11. Baskı). Ankara: Seçkin Yayıncilık.

\section{Introduction}

\section{Extended Abstract}

Writing is the effective transfer of feelings and thoughts onto paper. One of the biggest problems that teachers encounter while teaching writing skills to students is helping them apply the spelling rules. When the literature is examined, it is seen that there is only one study, carried out by Akkaya (2013), that researched the opinions of Turkish language teachers of the causes of misspelling. In this context, the aim of the study is to gather the opinions of Turkish language teachers regarding misspelled words, to determine why these words are not spelled correctly, and to offer solutions based on the opinions obtained.

\section{Method}

The interview technique, a qualitative research method, was used to determine the opinions of Turkish language teachers regarding misspelled words. Such interviews are divided into different types of focus group discussions-structured, unstructured, semi-structured, and ethnographicaccording to the availability of resources and the characteristics of the data to be collected in the research (Büyüköztürk, Kılıç Çakmak, Akgün, Karadeniz, \& Demirel, 2020). Of these, semi-structured interviews "unify both fixed responses and in-depth reasoning in the relevant domain" (Büyüköztürk, Kılıç Çakmak, Akgün, Karadeniz, \& Demirel, 2020, p. 159). In this context, the semi-structured interview technique, was used to collect data on the research subject. The research study group consisted of 45 
Turkish language teachers who taught Turkish language courses in the fifth, sixth, seventh, and eighth grades in the state or private schools affiliated with the central district of Çanakkale in the 2019-2020 academic year. In determining the research group, a simple random sampling method was the basis in which the probability of "each item or unit in the research population being included in the sample" (Gürbüz \& Şahin, 2018, p. 131) was equal. In the study, a 15-question semi-structured interview form prepared by the researcher was given to the teachers to determine the opinions of Turkish language teachers regarding misspelled words. Five of the questions in the interview form were for personal information, and 10 were for the research subject. The data obtained from the semi-structured interview forms were evaluated via content analysis. As a result of the evaluations made, the findings were grouped under 10 main themes, and direct quotations were also included.

\section{Result and Discussion}

The results of the interviews indicated that Turkish language teachers thought that students make mistakes in spelling abbreviations $(f=1)$, suffixes and reduplicates $(f=3)$, and numbers $(f=3)$ in descending order of frequency. This finding aligns with the findings by Akkaya (2013) in the study titled "6th Grade Students' Frequency of Orthographic Mistakes and Teachers' View About the Reasons for Orthographic Mistakes."

$14.67 \%$ of Turkish language teachers $(f=11)$ thought the fact that students do not read books was the main reason for students to misspell words, and $10.67 \%(f=8)$ thought the constant change in spelling rules was the main reason for students to misspell words. Batur, Erkek, Ertan Özen, and Ellialtı (2017, p. 63) stated, "Many reasons such as not being able to teach language rules adequately or in time (at the right age), not giving enough importance to the use of language socially, and not considering language rules in instant written communication can cause written expression errors and faulty expressions. However, it is easier for reading people to cope with these negativities than others" and referred to the fact that people who read books a lot make fewer spelling mistakes, and it was seen that these statements supported the ideas of the teachers.

$28.73 \%$ of Turkish language teachers $(f=27)$ stated that words are written very carelessly in the mass media, and $21.28 \%$ of them $(f=20)$ stated that mass media makes spelling mistakes permanent. The study titled "Digital Generation, Digital Communication, and the Digitalized (!) Turkish" by Karahisar (2013) also supported this situation. Karahisar underlined this situation as follows $(2013$, p. 76) "Another element that directly affects the use of language is the media. In our country, where the television watching habit is high, children in particular are faced with the misuse of language. The articles that do not comply with the grammatical rules on the screen cannot be noticed by children and are perceived as correct."

Maden and Maden (2018) emphasized the importance of using electronic dictionaries and spelling guides in their study titled "Electronic Dictionary and Spelling Book Use Habits of Turkish Teacher Candidates." In this study, $42.62 \%$ of Turkish language teachers $(f=26)$ stated that when they hesitated about the spelling of a word, they made use of the electronic dictionary on the official website of the Turkish Language Institution. In this context, it was seen that the use of electronic dictionaries and spelling guides has been increasingly adopted.

While $77.78 \%$ of Turkish language teachers $(f=35)$ stated that students should definitely use a spelling guide/dictionary, $8.89 \%$ of the teachers $(f=4)$ stated that, although they agree with this view, the internet can be used for this.

$57.5 \%$ of the teachers $(f=23)$ stated that they found it very logical that the Turkish Language Institute removed the spelling guide application on its web page and placed the spelling of words along with their meanings under the title of Contemporary Turkish Dictionary, and this change increased the functionality of the application.

$26.48 \%$ of the teachers $(f=18)$ who stated that objectives in the skill of writing in the Turkish Language course curriculum (secondary school including the fifth, sixth, seventh, and eighth grades) was not sufficient, and added that objectives in writing skills should be increased, especially in the fifth and sixth grades. When the 2019 Turkish Language Course Curriculum was examined in terms of acquisitions for writing skills, it was seen that there were 16 objectives in the fifth grade, 14 in the 
sixth grade, 17 in the seventh grade, and 20 in the eighth grade (MEB, 2019). When the 2015 Turkish Language Course Curriculum, which was the first program prepared for the Turkish language course after the transition to the $4+4+4$ education system, was examined, it was seen that there were both main and sub-objectives for writing skill. The distribution according to the grades was as follows: fifth grade, 13 main +16 sub-objectives; sixth grade, 13 main +16 sub-objectives; seventh grade, 11 main + 18 sub-objectives; 8th grade, 12 main +18 sub-objectives (MEB, 2015). In this context, when the main and sub-acquisitions were evaluated as a whole, it was understood that the objectives related to writing skills in the 2019 Turkish Language Course Curriculum were quite low compared to the ones in the 2015 Turkish Language Course Curriculum. However, in the 2019 Turkish Language Course Curriculum, it was seen that the teaching of spelling and punctuation should be completed in the first through fifth grades and there was no other objective than the following: "The student puts what he or she writes in order" related to the use of spelling rules and punctuation marks for the sixth, seventh, and eighth grades, and it was determined that there was not enough guidance regarding the application of spelling rules and the correct use of punctuation marks.

This situation supported the opinions of the teachers. $21.62 \%$ of the Turkish language teachers $(f=16)$ stated that writing activities should be done frequently and should be supported with games in order for students to better grasp spelling rules. In the study titled "A Recommendations on Correcting Writing Materials: Manas Play" by Batur and Özdil (2018), it was determined that the Manas Play developed by the researchers was effective in correcting the spelling mistakes, students made fewer mistakes when the preparation and practice papers were examined, and there were positive changes in their pronunciation and written expression. This conclusion supports the view of the Turkish language teachers that using activities and materials in teaching of words whose spelling is confused increases retention of the subject.

Suggestions that can be made based on the results are as follows:

- Strict and unchangeable rules should be introduced for the words whose spelling is confused due to the differences between spoken language and written language. For this, the spelling of the words should be clarified, and these spellings should be explained in a logical framework.

- Spelling should not be a set of rules that needs to be memorized, but the implementation of these rules should be supported by various activities and materials.

- Technological developments have had an impact on the ways we obtain information in many areas of our lives. This situation has paved the way for using electronic media to learn the meaning and spelling of words. For this reason, Turkish language teachers should have the habit of using technology correctly and beneficially, and they should support students in using technological resources effectively.

- Mass media such as television, magazines, newspapers, etc. have an important place in our daily life. In these tools, such mistakes as writing special names in small letters, incorrect spelling of suffixes in abbreviations, misuse of punctuation marks, etc. cause negative effects on language. Increasing control on mass media may be effective in preventing related mistakes. 